\title{
Snow scavenging and phase partitioning of nitrated and oxygenated aromatic hydrocarbons in polluted and remote environments in central Europe and the European Arctic
}

\author{
Pourya Shahpoury ${ }^{1,2}$, Zoran Kitanovski ${ }^{1,3}$, and Gerhard Lammel ${ }^{1,4}$ \\ ${ }^{1}$ Multiphase Chemistry Department, Max Planck Institute for Chemistry, Mainz, Germany \\ ${ }^{2}$ Air Quality Processes Research Section, Environment and Climate Change Canada, Toronto, Canada \\ ${ }^{3}$ Department of Food Chemistry, National Institute of Chemistry, Ljubljana, Slovenia \\ ${ }^{4}$ Research Centre for Toxic Compounds in the Environment, Masaryk University, Brno, Czech Republic
}

Correspondence: Pourya Shahpoury (p.shahpoury@mpic.de)

Received: 1 January 2018 - Discussion started: 6 February 2018

Revised: 25 June 2018 - Accepted: 10 July 2018 - Published: 24 September 2018

\begin{abstract}
Nitrated and oxygenated polycyclic aromatic hydrocarbons (N/OPAHs) are emitted in combustion processes and formed in polluted air. Their environmental cycling through wet deposition has hardly been studied. Fresh snow samples at urban and rural sites in central Europe, as well as surface snow from a remote site in Svalbard, were analysed for 17 NPAHs, 8 OPAHs, and 11 nitrated mono-aromatic hydrocarbons (NMAHs), of which most N/OPAHs as well as nitrocatechols, nitrosalicylic acids, and 4-nitroguaiacol are studied for the first time in precipitation. In order to better understand the scavenging mechanisms, the particulate mass fractions $(\theta)$ at $273 \mathrm{~K}$ were predicted using a multi-phase gasparticle partitioning model based on polyparameter linear free energy relationships. $\sum$ NPAH concentrations were 1.217.6 and $8.8-19.1 \mathrm{ng} \mathrm{L}^{-1}$ at urban and rural sites, whereas $\sum$ OPAHs were $79.8-955.2$ and $343.3-1757.4 \mathrm{ng} \mathrm{L}^{-1}$ at these sites, respectively. 9,10-anthraquinone was predominant in snow aqueous and particulate phases. NPAHs were only found in the particulate phase with 9-nitroanthracene being predominant followed by 2-nitrofluoranthene. Among NMAHs, 4-nitrophenol showed the highest abundance in both phases. The levels found for nitrophenols were in the same range or lower than those reported in the 1980s and 1990s. The lowest levels of $\sum$ N/OPAHs and $\sum$ NMAHs were found at the remote site ( 3.5 and $390.5 \mathrm{ng} \mathrm{L}^{-1}$, respectively). N/OPAHs preferentially partitioned in snow particulate phase in accordance with predicted $\theta$, whereas NMAHs were predominant in the aqueous phase, regardless of $\theta$. It is concluded that the phase distribution of non-polar N/OPAHs in snow is determined by their gas-particle partitioning prior
\end{abstract}

to snow scavenging, whereas that for polar particulate phase substances, i.e. NMAHs, is determined by an interplay between gas-particle partitioning in the aerosol and dissolution during in- or below-cloud scavenging.

\section{Introduction}

Nitrated and oxygenated polycyclic aromatic hydrocarbons (N/OPAHs) are formed primarily by oxidation of parent PAHs during combustion of fossil fuels as well as biomass burning, and secondarily through reactions of PAHs with atmospheric oxidants, such as $\mathrm{O}_{3}, \mathrm{OH}$ and $\mathrm{NO}_{x}$ (Walgraeve et al., 2010; Bandowe and Meusel, 2017). N/OPAHs were found in emissions from gasoline, diesel and biodiesel (Zielinska et al., 2004; Karavalakis et al., 2010; Pham et al., 2013), biomass and coal burning (Ding et al., 2012; Shen et al., 2012, 2013a, b; Huang et al., 2014; Vicente et al., 2016), and solid waste incineration (Watanabe and Noma, 2009). These substance groups were also suggested to play a role in light absorption properties of biomass burning particulate matter (PM) (Lin et al., 2016). Some NPAHs, e.g. 3-nitrofluoranthene (3-NFLT) and 1nitropyrene (1-NPYR), are associated specifically with combustion sources, whereas others such as 2-nitrofluoranthene (2-NFLT) and 2-nitropyrene (2-NPYR) are produced through gas phase reaction of FLT and PYR with OH radicals and $\mathrm{NO}_{x}$ (Arey et al., 1986; Bandowe and Meusel, 2017). NPAHs are also formed through reactions in the aerosol condensed phase (Keyte et al., 2013; Jariyasopit et al., 2014). Pho- 
tolysis of NPAHs results in the formation of other oxygenated and nitrated species such as hydroxynitro-PAHs, quinones, and nitrated quinones (Bandowe and Meusel, 2017). Unlike NPAHs, there is no agreement on distinct formation pathways of individual OPAHs - to various extents, they originate from both primary and secondary sources (Walgraeve et al., 2010; Zhuo et al., 2017). For instance, 9-fluorenone (9-OFLN), 9,10-anthraquinone $\left(9,10-\mathrm{O}_{2} \mathrm{ANT}\right), 1,4-$ naphthoquinone $\left(1,4-\mathrm{O}_{2} \mathrm{NAP}\right)$, and 1,2benzanthraquinone $\left(1,2-\mathrm{O}_{2} \mathrm{BAA}\right)$ were previously found in diesel exhaust (Choudhury, 1982; Cho et al., 2004) and biomass and coal burning emissions (Shen et al., 2013a; Huang et al., 2014; Vicente et al., 2016), whereas in ambient PM, 9-OFLN, 9,10- $\mathrm{O}_{2}$ ANT, and 1,2- $\mathrm{O}_{2} \mathrm{BAA}$ were attributed to both primary and secondary sources (Kojima et al., 2010; Souza et al., 2014; Lin et al., 2015; Zhuo et al., 2017). The contribution of primary sources is expected to be higher during the cold season, with heating activities dominating the vehicular emission (Lin et al., 2015). Interestingly, benzanthrone (OBAT) does not have a stable parent PAH precursor with the same number of rings in the atmosphere (Kojima et al., 2010). This substance, together with benz(a)fluorenone (BaOFLN) and benz(b)fluorenone (BbOFLN), was associated with primary combustion sources (Albinet et al., 2007; Karavalakis et al., 2010; Shen et al., 2013b; Huang et al., 2014; Souza et al., 2014; Tomaz et al., 2016; Vicente et al., 2016). One must also note the possibility of NPAH conversion to OPAHs in the atmosphere. For instance, the formation of 1,4- $\mathrm{O}_{2} \mathrm{NAP}$ and 9,10- $\mathrm{O}_{2}$ ANT following photolysis of 1-nitronaphthalene (1NNAP) and 9-nitroanthracene (9-NANT) was suggested by previous studies (Keyte et al., 2013; Bandowe and Meusel, 2017).

Many N/OPAHs are suggested to be more mutagenic than their parent species and are also classified as possible carcinogens (Finlayson-Pitts and Pitts, 2000; Lammel, 2015). Moreover, quinones, a prominent sub-class of OPAHs, are precursors of environmentally persistent free radicals (Borrowman et al., 2016) and reactive oxygen species (Chung et al., 2006; Charrier et al., 2014), inducing oxidative stress and inflammatory reactions in organisms, which may lead to cellular damage and respiratory and cardiovascular disease (Lodovici and Bigagli, 2011; Møller et al., 2014; Kelly and Fussell, 2017).

Nitrated mono-aromatic hydrocarbons (NMAHs) are composed of several chemically related compound classes such as: nitrophenols, nitroguaiacols, nitrocatechols, and hydroxy-nitrobenzoic (i.e. nitrosalicylic) acids, which among others contain nitro, hydroxyl, and carboxyl functionalities (Chow et al., 2016). Nitrophenols are emitted from primary sources, particularly biomass burning but also traffic exhaust (Tremp et al., 1993), or formed in secondary processes - nitration of precursors such as phenol in the atmosphere (Harrison et al., 2005). Nitrocatechols and nitrosalicylic acids are mainly secondary oxidation products of substituted phe- nols (alkylphenols, methoxyphenols, hydroxybenzoic acids) emitted in primary aerosols from biomass (e.g. wood) burning (Iinuma et al., 2007, 2010; Kitanovski et al., 2012; Kahnt et al., 2013; Chow et al., 2016). Increased production of nitrocatechols in the urban environment due to anthropogenic activities, such as wood burning in winter, was suggested by previous studies (Kitanovski et al., 2012; Chow et al., 2016). Kitanovski et al. (2012) reported a high correlation between concentrations of nitrocatechols and nitrosalicylic acids $\left(R^{2}>0.8\right)$ in urban PM, which suggests secondary formation of nitrosalicylic acids as well as biomass burning as the major emission source, similar to the previous reports on nitrocatechols (Iinuma et al., 2010; Kitanovski et al., 2012; Kahnt et al., 2013; Caumo et al., 2016; Chow et al., 2016).

NMAHs are ecotoxic (Pflieger and Kroflič, 2017) while little is known about human toxicity (Huang et al., 1995; Harrison et al., 2005; Kovacic and Somanathan, 2014). Due to nitrophenol phytotoxic potential, the research on them in precipitation was fostered during the late 1980s and early 1990s in relation with research on forest decline in central Europe (Rippen et al., 1987; Leuenberger et al., 1988; Herterich and Herrmann, 1990). Last but not least, NMAHs significantly contribute to the light-absorptive properties of PM organic carbon (Mohr et al., 2013; Hinrichs et al., 2016; Bluvshtein et al., 2017; Teich et al., 2017) and can influence climate by altering Earth's albedo.

Semi-volatile organic compounds (SVOCs) in the atmosphere are subject to removal by dry particle deposition and wet scavenging. The latter consists of two processes - i.e. particle scavenging and gas scavenging. The particle scavenging is relevant for SVOCs that show higher affinity towards the particulate phase (Bidleman, 1988; Shahpoury et al., 2015). This is affected by SVOC gas-particle partitioning (GPP) in the aerosol, a process controlled mainly by the substance molecular structure, PM chemical composition, and ambient temperature (Shahpoury et al., 2016). The magnitude of SVOC sorption to PM is defined by its particulate mass fraction, $\theta$ Eq. (1):

$\theta=c_{\mathrm{p}} /\left(c_{\mathrm{p}}+c_{\mathrm{g}}\right)$

where $c_{\mathrm{p}}$ and $c_{\mathrm{g}}$ are concentrations of SVOC $\left(\mathrm{ng} \mathrm{m}^{-3}\right)$ in the particulate and gas phases, respectively. The gas scavenging is relevant for substances which demonstrate minimum interaction with PM and therefore remain to various extents in the gas phase. Although gas scavenging is affected by GPP, the actual removal from the atmosphere is due to substance dissolution in cloud or rain droplets or sorption to snowflakes or other ice hydrometeors (Hoff et al., 1995; Bartels-Rausch et al., 2014). Following wet scavenging, SVOCs in the gas and particulate phases in the atmosphere accumulate in precipitation aqueous and particulate phases, respectively. The fraction of SVOCs removed by particle scavenging is given by $\theta_{\mathrm{w}}$ Eq. (2):

$\theta_{\mathrm{w}}=c_{\mathrm{pp}} /\left(c_{\mathrm{pp}}+c_{\mathrm{pa}}\right)$, 
where $c_{\mathrm{pp}}$ and $c_{\mathrm{pa}}$ are analyte concentrations $\left(\mathrm{ng} \mathrm{L}^{-1}\right)$ in precipitation particulate and aqueous phases, respectively. It has been shown that the magnitude of particle scavenging is generally higher than gas scavenging for hydrophobic SVOCs such as PAHs (Atlas and Giam, 1988; Bidleman, 1988; Shahpoury et al., 2015). In principle, for such substances one could apply $\theta$ as an indicator for predicting the SVOC wet particle scavenging - i.e. the higher the $\theta$ at a given temperature, the more efficient is the scavenging, and the magnitude of $\theta_{\mathrm{w}}$ is expected to be close to $\theta$. However, it is anticipated that for hydrophilic SVOCs, which may demonstrate low or high $\theta$, water solubility plays an additional role in the substance wet scavenging pathways and the comparability of $\theta_{\mathrm{w}}$ with $\theta$. For instance, a NMAH with high $\theta$ in the atmosphere may demonstrate low $\theta_{\mathrm{w}}$ due to substance dissolution in hydrometeors following particle scavenging. Conversely, a NMAH with low $\theta$ is expected to show low $\theta_{\mathrm{w}}$, as it undergoes the gas scavenging process.

The efficiency of SVOC wet scavenging is defined by $W_{T}$ (unitless) (Bidleman, 1988; Poster and Baker, 1996; Škrdlíková et al., 2011; Shahpoury et al., 2015) Eq. (3):

$W_{T}=\left(c_{\text {snow }} \times 1000\right) / c_{\text {air }}$,

where $c_{\text {snow }}$ is the total analyte concentration in snow meltwater $(\mathrm{ng} \mathrm{L}-1)$ and $c_{\text {air }}$ is that $\left(\mathrm{ng} \mathrm{m}^{-3}\right)$ in ambient air.

There is currently very limited information in the literature about the occurrence of N/OPAHs and NMAHs in precipitation, except for small number of OPAHs (Kawamura and Kaplan, 1983) and nitrophenols: 4-nitrophenol (4$\mathrm{NP}$ ), several methyl-nitrophenol isomers as well as dinitrophenols, 2,4-dinitrophenol (2,4-DNP), and 2-methyl-4,6dinitrophenol (i.e. dinitro-ortho-cresol, DNOC) have been the most frequently measured nitrophenols in precipitation in urban and rural Europe (Leuenberger et al., 1988; Alber et al., 1989; Herterich and Herrmann, 1990; Levsen et al., 1990, 1991, 1993; Schüssler and Nitschke, 2001; Bossi et al., 2002; Kohler and Heeb, 2003; Asman et al., 2005; Belloli et al., 2006; Jaber et al., 2007; Schummer et al., 2009), North America (Ganranoo et al., 2010), and Antarctica (Vanni et al., 2001) (Table S1 in the Supplement).

The aims of the present study were (1) to investigate the presence of N/OPAHs and NMAHs in the aqueous and particulate phases of fresh snow; (2) estimate the substance particulate mass fractions in the atmosphere using a multi-phase GPP model, based on poly-parameter linear free energy relationships (ppLFERs); and (3) determine the substance fractions removed by wet particle scavenging, and explore the effect of GPP vs. water solubility on target compound wet scavenging. For calculating $\theta$, our method took into account the interaction of atmospheric SVOCs with PM liquid organic and polymeric phases, as well as the interaction with PM black carbon and salts, while disregarding the partitioning into PM aqueous phase, particle-liquid interactions, and liquid-liquid phase separation within PM (Sect. 2.6).

\section{Experimental}

\subsection{Sampling}

Snow samples were collected between winter 2015 and 2017 from three locations in Germany, i.e. Mainz (MZ15 and MZ17; urban-residential, $\approx 200000$ inhabitants), Winterberg (WB), and Altenberg (AB; rural, $>10 \mathrm{~km}$ from small towns); two locations in Inn Valley, Austria, i.e. Götzens (GS; urban-residential of a mid-sized city, Innsbruck, $\approx$ 140000 inhabitants) and Kolsassberg (KB; rural, 10-20 km from city and towns); two locations in the Czech Republic, i.e. Ostrava (OS; urban, conurbation with $\approx 700000$ inhabitants) and Pustá Polom (PP1 and PP2; rural, $20 \mathrm{~km}$ upwind from Ostrava); and one location in the Arctic, Tempelfjorden, Svalbard (TF, remote, $50-80 \mathrm{~km}$ from small towns). The sample site details are shown in Table 1. Fresh snow samples (all sites, except TF) were collected by placing several polypropylene trays $\left(0.25 \mathrm{~m}^{2}\right.$ each) on the ground prior to snowfall. To this end, the snow forecast for a number of preselected sites was monitored on a daily basis. Both collection trays and bottles were pre-cleaned prior to sample collection in the lab using detergent, tap water, deionized water, and high-purity ethanol. The snow was transferred with compaction in amber $2 \mathrm{~L}$ bottles and kept frozen at $-18^{\circ} \mathrm{C}$ until analysis. Dry and light surface snow $(0-5 \mathrm{~cm}$ deep, somewhat harder at the surface), which had fallen 3-2 days before, was collected at TF and stored in pre-cleaned amber bottles. Following this sample collection and storage procedure, we rely on exclusion of significant phase change during storage and prior to sample processing.

\subsection{Sample processing}

Our sample processing was performed in such way to minimize the analyte phase change prior to analysis; i.e. the samples were thawed at room temperature in the lab and, immediately after thawing, when the samples were near freezing point, the meltwater was passed through a preassembled filtration-extraction set-up (Fig. S1 in the Supplement), which allowed the simultaneous separation of meltwater particulate phase and extraction of aqueous phase. This made it possible to minimize the time that particles were in contact with the aqueous phase of meltwater. The set-up consisted of a pre-assembled sterile analytical filter funnel (250 mL, graduated, Nalgene, Thermo Scientific, Waltham, MA, USA), connected to a solid-phase extraction (SPE) disk (Bakerbond Speedisk, J.T. Baker, the Netherlands) using a Teflon adaptor designed in-house (Fig. S1). This was assembled on a J.T. Baker extraction station connected to a vacuum pump. A steady sample flow $\left(10 \mathrm{~mL} \mathrm{~min}^{-1}\right)$ was established between the filter funnel and Speedisk throughout sample processing, by occasionally applying vacuum, where needed. The volume of meltwater for each sample was determined during filtration using the graduated filter funnel (Fig. S1) 
Table 1. Sampling site details.

\begin{tabular}{|c|c|c|c|c|c|}
\hline & Coordinates & $\begin{array}{r}\text { Sampling } \\
\text { date }\end{array}$ & $\begin{array}{c}\text { Snowfall } \\
\text { started }\end{array}$ & $\begin{array}{r}\text { Sample } \\
\text { collected }\end{array}$ & $\begin{array}{l}\text { Snowmelt } \\
\text { volume }(\mathrm{L})\end{array}$ \\
\hline \multicolumn{6}{|l|}{ Urban } \\
\hline MZ15, Mainz & $49.99^{\circ} \mathrm{N}, 8.23^{\circ} \mathrm{E}$ & 23 Feb 2015 & 08:00 & $12: 45$ & 0.4 \\
\hline GS, Götzens & $47.23^{\circ} \mathrm{N}, 11.31^{\circ} \mathrm{E}$ & 25 Feb 2015 & Overnight & 09:00 & 0.45 \\
\hline OS, Ostrava & $49.86^{\circ} \mathrm{N}, 18.26^{\circ} \mathrm{E}$ & 19 Feb 2016 & $14: 00$ & 19:00 & 0.5 \\
\hline MZ17, Mainz & $49.99^{\circ} \mathrm{N}, 8.23^{\circ} \mathrm{E}$ & 10 Jan 2017 & 09:00 & $15: 00$ & 1 \\
\hline \multicolumn{6}{|l|}{ Rural } \\
\hline WB, Winterberg & $51.18^{\circ} \mathrm{N}, 8.49^{\circ} \mathrm{E}$ & 03 Mar 2015 & 15:00 & $18: 30$ & 0.5 \\
\hline $\mathrm{AB}$, Altenberg & $50.78^{\circ} \mathrm{N}, 13.69^{\circ} \mathrm{E}$ & 05 Mar 2015 & Overnight & 08:00 & 0.5 \\
\hline KB, Kolsassberg & $47.28^{\circ} \mathrm{N}, 11.65^{\circ} \mathrm{E}$ & 25 Feb 2015 & Overnight & $10: 00$ & 0.5 \\
\hline PP1, Pustá Polom 1 & $49.86^{\circ} \mathrm{N}, 17.98^{\circ} \mathrm{E}$ & 19 Feb 2016 & 09:30 & 23:00 & 0.5 \\
\hline PP2, Pustá Polom 2 & $49.86^{\circ} \mathrm{N}, 17.98^{\circ} \mathrm{E}$ & 23 Feb 2016 & $14: 00$ & 23:00 & 0.5 \\
\hline \multicolumn{6}{|l|}{ Remote } \\
\hline TF, Tempelfjorden & $78.45^{\circ} \mathrm{N} 17.32^{\circ} \mathrm{E}$ & 4 Mar 2015 & 1 Mar 2015 & after snowfall $^{\mathrm{a}}$ & 1.65 \\
\hline
\end{tabular}

${ }^{a}$ Old snow, fallen 3-2 days before sampling.

and used for calculating the final analyte concentrations in aqueous and particulate phases. The $\mathrm{pH}$ of meltwater samples was 4.5-5.

\section{$2.3 \quad$ N/OPAH extraction and chemical analysis}

A $0.22 \mu \mathrm{m}$ cellulose nitrate filter in $250 \mathrm{~mL}$ analytical filter funnel and octadecyl (C18) Speedisks were used for N/OPAH extraction. Speedisks were pre-conditioned with $50 \mathrm{~mL}$ of methanol followed by $10 \mathrm{~mL}$ of deionized water and spiked with a mixture of deuterated standards, containing $75 \mathrm{ng}$ of 1-nitronaphthalene- $\mathrm{d}_{7}, 2$-nitrofluorene- $\mathrm{d}_{9}$, 9-nitroanthracene- $d_{9}, 3$-nitrofluoranthene-d 9 , 1-nitropyrene$\mathrm{d}_{9}$, 6-nitrochrysene- $\mathrm{d}_{11}, 9,10$-anthraquinone- $\mathrm{d}_{8}$, and 9fluorenone- $\mathrm{d}_{8}$. Filter papers containing the particulate phase samples were spiked with the same standard mixture after sample processing prior to their extraction. After loading the samples, Speedisks were capped with aluminium foil and dried by pumping air through them for $5 \mathrm{~min}$.

The filter papers containing the particulate phase samples were extracted following a QuEChERS method (Albinet et al., 2014). Briefly, each filter paper was placed in a glass centrifuge tube (Duran, Schott, Mainz, Germany) and added with $7 \mathrm{~mL}$ of dichloromethane (DCM). The centrifuge tubes were capped with screw caps containing PTFE lining. Each sample was vortexed for $1.5 \mathrm{~min}$, passed through a glass funnel plugged with a small amount of deactivated glass wool (in order to remove residual sample matrix), and concentrated to $0.5 \mathrm{~mL}$ using a Turbovap II (Biotage, Uppsala, Sweden). The extracts were later loaded on a pre-conditioned $500 \mathrm{mg} \mathrm{SiO} 2$ cartridge (Macherey-Nagel, Weilmünster, Germany), and eluted with $9 \mathrm{~mL}$ of $65: 35 n$-hexane-DCM. The aqueous phase samples enriched on $\mathrm{C} 18$ Speedisks were eluted with $40 \mathrm{~mL}$ of $1: 1 n$-hexane-DCM. All extracts from particulate and aqueous phases were concentrated to $0.5 \mathrm{~mL}$ and the solvent was exchanged to ethyl acetate $(3 \times 5 \mathrm{~mL})$. The sample volumes were further adjusted to $0.3 \mathrm{~mL}$ and transferred to $2 \mathrm{~mL}$ vials containing pre-baked $0.4 \mathrm{~mL}$ glass inserts for further analysis. All other glassware used for sample analysis was washed with lab-grade detergent and deionized water and baked at $300^{\circ} \mathrm{C}$ for $12 \mathrm{~h}$. All solvents used for N/OPAH analysis were Suprasolv grade (Merck, Darmstadt, Germany).

The samples were analysed using a Trace 1310 gas chromatograph (GC, Thermo Scientific, Waltham, MA, USA) coupled to a TSQ8000 Evo triple-quadrupole mass selective detector (MS/MS, Thermo Scientific) in negative chemical ionization and selected ion monitoring (SIM) modes. The analyte separation was achieved on a J\&W DB-5ms column $(30+10 \mathrm{~m}$ integrated guard, $0.25 \mathrm{~mm}$ ID, $0.25 \mu \mathrm{m}$ film thickness, Santa Clara, CA, USA) with helium ( $99.9999 \%$; Westfalen AG, Münster, Germany) as carrier gas at $1 \mathrm{~mL} \mathrm{~min}^{-1}$ flow rate. The GC operating conditions were as follows: the $\mathrm{GC}$ oven was held at $60^{\circ} \mathrm{C}$ for $2 \mathrm{~min}$, then ramped to $180^{\circ} \mathrm{C}$ at $15^{\circ} \mathrm{C} \mathrm{min}-1$, followed by a $5^{\circ} \mathrm{C} \mathrm{min}^{-1}$ ramp to $280^{\circ} \mathrm{C}$ and final hold time of $15 \mathrm{~min}$. The injection port temperature was set to $250^{\circ} \mathrm{C}$ and operated in pulsed splitless mode (30 psi pulsed pressure for $1.5 \mathrm{~min}$, and splitless time of $1.8 \mathrm{~min})$. MS transfer line and ion source temperature were set to 290 and $230^{\circ} \mathrm{C}$, respectively. Methane (>99.9995, Messer, Bad Soden, Germany) was used as ionization gas with $1.5 \mathrm{~mL} \mathrm{~min}^{-1}$ flow rate. Emission current and electron energy were set to $100 \mu \mathrm{A}$ and $-70 \mathrm{eV}$, respectively. The samples were analysed for N/OPAHs listed in Table 2. Each target analyte was identified using its retention time and 
Table 2. Target compound list.

\begin{tabular}{|c|c|c|c|c|}
\hline Analyte & Abbreviation & RT & Q1 & Detection* \\
\hline 1-Nitronaphthalene & 1-NNAP & 12.12 & 173 & $\mathrm{P}(86)$ \\
\hline 2-Nitronaphthalene & 2-NNAP & 12.62 & 173 & $\mathrm{P}(43)$ \\
\hline 5-Nitroacenaphthene & 5-NACE & 17.52 & 199 & n.d. \\
\hline 2-Nitrofluorene & 2-NFLN & 19.07 & 211 & n.d. \\
\hline 9-Nitroanthracene & 9-NANT & 19.46 & 223 & $\mathrm{P}(71)$ \\
\hline 9-Nitrophenanthrene & 9-NPHE & 20.64 & 223 & n.d. \\
\hline 3-Nitrophenanthrene & 3-NPHE & 21.4 & 223 & n.d. \\
\hline 2-Nitrofluoranthene & 2-NFLT & 25.75 & 247 & $\mathrm{P}(71)$ \\
\hline 3-Nitrofluoranthene & 3-NFLT & 25.80 & 247 & n.d. \\
\hline 1-Nitropyrene & 1-NPYR & 26.63 & 247 & n.d. \\
\hline 2-Nitropyrene & 2-NPYR & 26.95 & 247 & n.d. \\
\hline 7-Nitrobenz(a)anthracene & 7-NBAA & 29.41 & 273 & n.d. \\
\hline 6-Nitrochrysene & 6-NCHR & 30.66 & 273 & n.d. \\
\hline 1,3-Dinitropyrene & $1,3-\mathrm{N}_{2} \mathrm{PYR}$ & 31.8 & 292 & n.d. \\
\hline 1,6-Dinitropyrene & $1,6-\mathrm{N}_{2} \mathrm{PYR}$ & 32.81 & 292 & n.d. \\
\hline 1,8-Dinitropyrene & $1,8-\mathrm{N}_{2} \mathrm{PYR}$ & 33.54 & 292 & n.d. \\
\hline 6-Nitrobenz(a)pyrene & 6-NBAP & 36.73 & 297 & n.d. \\
\hline 1,4-Naphthoquinone & $1,4-\mathrm{O}_{2} \mathrm{NAP}$ & 10.18 & 158 & $\mathrm{~A}(14)$ \\
\hline 9-Fluorenone & 9-OFLN & 13.78 & 180 & $A(100)$ P (86) \\
\hline 9,10-Anthraquinone & $9,10-\mathrm{O}_{2} \mathrm{ANT}$ & 17.03 & 208 & A (86) P (57) \\
\hline 2-Nitro-9-fluorenone & 2-N-9-OFLN & 20.54 & 225 & n.d. \\
\hline Benz(a)fluorenone & $\mathrm{BaOFLN}$ & 22.88 & 230 & A (29) P (100) \\
\hline Benz(b)fluorenone & BbOFLN & 23.82 & 230 & $\mathrm{P}(86)$ \\
\hline Benzanthrone & OBAT & 25.07 & 230 & A (29) B (43) \\
\hline 1,2-Benzanthraquinone & $1,2-\mathrm{O}_{2} \mathrm{BAA}$ & 26.46 & 258 & A (71) B (100) \\
\hline 3-Nitrosalicylic acid & 3-NSA & 3.60 & 182 & A (100) P (11) \\
\hline 5-Nitrosalicylic acid & 5-NSA & 5.07 & 182 & A (100) P (11) \\
\hline 4-Nitrocatechol & 4-NC & 7.76 & 154 & A (90) P (33) \\
\hline 4-nitroguaiacol & $4-\mathrm{NG}$ & 8.29 & 168 & $A(50) P(22)$ \\
\hline 4-Methyl-5-nitrocatechol & 4-M-5-NC & 9.47 & 168 & A (90) P (22) \\
\hline 4-Nitrophenol & 4-NP & 10.00 & 138 & $\mathrm{~A}(100) \mathrm{P}(100)$ \\
\hline 2,4-Dinitrophenol & 2,4-DNP & 10.92 & 183 & A (100) P (33) \\
\hline 3-Methyl-4-nitrophenol & 3-M-4-NP & 13.19 & 152 & A (100) P (89) \\
\hline 3-Methyl-5-nitrocatechol & 3-M-5-NC & 14.01 & 168 & $A(100) P(22)$ \\
\hline 2-Methyl-4-nitrophenol & 2-M-4-NP & 16.72 & 152 & A (100) P (89) \\
\hline Dinitro-ortho-cresol & DNOC & 17.05 & 197 & A (100) P (78) \\
\hline
\end{tabular}

Abbreviations, retention times (RT), and quantification ions (Q1) of target analytes; * analyte detection in aqueous (A) or particulate $(\mathrm{P})$ phase; numbers in brackets indicate percentage of detection across the samples in each phase; n.d.: not detected.

quantification ion (Table 2). The analyte quantification was carried using the internal calibration method with 11-point calibration curves ranging from 0.25 to $1000 \mathrm{pg} \mu \mathrm{L}^{-1}$.

\subsection{NMAH extraction and chemical analysis}

A $0.22 \mu \mathrm{m}$ cellulose acetate filter in the $250 \mathrm{~mL}$ analytical filter funnel and divinylbenzene hydrophilic Speedisk were used for NMAH extraction. The detailed analytical method is described in a companion paper (Kitanovski and Naumoska, in preparation). Briefly, the pre-conditioned Speedisk was spiked with $100 \mathrm{ng}$ of 4-nitrophenol- $\mathrm{d}_{4}$, and the sample $(250 \mathrm{~mL})$ was acidified with $2 \mathrm{~mL}$ of formic acid and passed through the disk. The elution of NMAHs from the disks was carried out using a mixture of acetonitrile and methanol containing $3.4 \mu \mathrm{M}$ ethylenediaminetetraacetic acid (EDTA). The presence of EDTA in the elution solvent was necessary for complete recovery of the NMAHs from the polymeric disks. The SPE extracts were further concentrated to near dryness using TurboVap II and later dissolved in a mixture of methanol and $7.15 \mathrm{mM}$ ammonium formate buffer of $\mathrm{pH} 3$ (3: $7, v / v)$, containing $400 \mu \mathrm{M}$ EDTA.

The PM retained on the cellulose acetate filters was spiked with the same quantity of 4-nitrophenol- $\mathrm{d}_{4}$ and extracted using a previously published procedure (Kitanovski et al., 2012). Briefly, the particles were extracted using methanol containing $3.4 \mu \mathrm{M}$ EDTA with agitation $(3 \times 5 \mathrm{~min})$ in an ul- 
trasonic bath. The final extracts were concentrated to near dryness, and dissolved in a mixture of methanol and $7.15 \mathrm{mM}$ ammonium formate buffer of $\mathrm{pH} 3(3 / 7, v / v)$, containing $400 \mu \mathrm{M}$ EDTA. All samples were analysed using a 1200 Series liquid chromatograph (LC; Agilent Technologies, Santa Clara, CA, USA) coupled to a 6130 single-quadrupole MS (Agilent Technologies) with an electrospray ionization (ESI) source. Separation was achieved on an Atlantis T3 column $(150 \times 2.1 \mathrm{~mm}$ ID, $3 \mu \mathrm{m}$; Waters, Milford, MA, USA), thermostated at $30^{\circ} \mathrm{C}$ during sample analysis. The NMAH elution was carried out using 30 : 15 : 55 methanoltetrahydrofuran-aqueous ammonium formate buffer $(5 \mathrm{mM}$, pH3) mobile phase in isocratic mode. The deprotonated NMAHs $[\mathrm{M}-\mathrm{H}]^{-}$listed in Table 2 were detected in negative ion ESI and SIM modes. The analyte quantification was carried out using the internal calibration method in the concentration range $1-500 \mathrm{pg} \mathrm{L}^{-1}$.

\subsection{Quality control}

Field blanks were prepared during sample collection by exposing the pre-cleaned sample bottles with an open cap to air for $5 \mathrm{~min}$ at the sites. The inner wall of the bottles was rinsed with $500 \mathrm{~mL}$ of deionized water in the lab and processed as field blank along with the rest of samples. Limits of quantification (LOQs) for analytes were calculated based on instrument detection limits (IDLs), which in turn are determined using 3 times the chromatogram baseline noise level. LOQ values were determined as mean concentration of each analyte in blanks +3 standard deviation. For this purpose, blank values that were < IDL were replaced with IDL values. Where analyte concentrations in samples exceeded the LOQ, mean blank concentrations were subtracted from those in the corresponding samples.

\subsection{Estimation of particulate mass fractions}

The $\theta$ for target analytes were estimated using modelled GPP constants, $K_{\mathrm{P}}\left(\mathrm{m}^{3} \mathrm{~g}^{-1}\right.$ at $\left.273.15 \mathrm{~K}\right)$, which were calculated using a multi-phase ppLFER model (Shahpoury et al., 2016). The model differentiates between various organic and inorganic phases of PM and accounts for absorption into water soluble organic matter (WSOM) and organic polymers (OPs), as well as adsorption onto black carbon or soot, $\left(\mathrm{NH}_{4}\right)_{2} \mathrm{SO}_{4}$, and $\mathrm{NaCl}$, Eq. (4):

$$
\begin{aligned}
K_{\mathrm{P}}\left(\mathrm{m}_{\mathrm{air}}^{3} \mathrm{~g}_{\mathrm{PM}}^{-1}\right)=[ & \left(K_{\mathrm{BC}} \times a_{\mathrm{BC}} \times f_{\mathrm{BC}}+K_{\left(\mathrm{NH}_{4}\right)_{2} \mathrm{SO}_{4}}\right. \\
& \times a_{\left(\mathrm{NH}_{4}\right)_{2} \mathrm{SO}_{4}} \times f_{\left(\mathrm{NH}_{4}\right)_{2} \mathrm{SO}_{4}}+K_{\mathrm{NaCl}} \\
& \left.\times a_{\mathrm{NaCl}} \times f_{\mathrm{NaCl}}\right)+\left(K_{\mathrm{DMSO}} / \rho_{\mathrm{DMSO}}\right. \\
& \left.\left.\times f_{\mathrm{WSOM}}+K_{\mathrm{PU}} \times f_{\mathrm{OP}}\right)\right]
\end{aligned}
$$

where $K_{\mathrm{BC}}, K_{\left(\mathrm{NH}_{4}\right)_{2} \mathrm{SO}_{4}}$, and $K_{\mathrm{NaCl}}$ are the target substance partitioning coefficients $\left(\mathrm{mol} \mathrm{m}_{\text {surface }}^{-2} / \mathrm{mol} \mathrm{m}_{\text {air }}^{-3}\right)$ for black carbon or diesel soot, $\left(\mathrm{NH}_{4}\right)_{2} \mathrm{SO}_{4}$ and $\mathrm{NaCl}$ (the last two represent the contributions of secondary inorganic aerosols and sea salt), respectively; $a_{\mathrm{BC}}, a_{\left(\mathrm{NH}_{4}\right)_{2} \mathrm{SO}_{4}}$, and $a_{\mathrm{NaCl}}$ are the adsorbent specific surface areas $\left(\mathrm{m}_{\text {surface }}^{2} \mathrm{~g}_{\text {adsorbent }}^{-1}\right)$; and $f_{\mathrm{BC}}, f_{\left(\mathrm{NH}_{4}\right)_{2} \mathrm{SO}_{4}}$, and $f_{\mathrm{NaCl}}$ are their mass mixing ratios in PM (gadsorbent $\mathrm{g}_{\mathrm{PM}}^{-1}$ ). For $a_{\mathrm{BC}}$, the geometric mean of $18.21 \mathrm{~m}^{2} \mathrm{~g}^{-1}$ was calculated from the values reported for traffic, wood, coal, and diesel soot (Jonker and Koelmans, 2002), whereas $a_{\left(\mathrm{NH}_{4}\right)_{2} \mathrm{SO}_{4}}$ and $a_{\mathrm{NaCl}}$ of 0.13 and $0.10 \mathrm{~m}^{2} \mathrm{~g}^{-1}$ were taken from Goss et al. (2003). $K_{\text {DMSO }}$ $\left(\mathrm{m}_{\text {air }}^{3} \mathrm{~m}_{\mathrm{DMSO}}^{-3}\right)$ and $K_{\mathrm{PU}}\left(\mathrm{m}_{\mathrm{air}}^{3} \mathrm{~g}_{\mathrm{PU}}^{-1}\right)$ are the substance partitioning (absorption) coefficients for dimethyl sulfoxide-air and polyurethane-air partitioning systems; $\rho_{\text {DMSO }}$ is dimethyl sulfoxide density $\left(\mathrm{g} \mathrm{m}^{-3}\right) ; f_{\mathrm{WSOM}}$ and $f_{\mathrm{OP}}$ are mass mixing ratios of absorbing phases ( $g_{\text {absorbent }} g_{P M}^{-1}$ ), corresponding to $f_{\mathrm{OM}}$ (the mixing ratio of total organic matter in $\mathrm{PM}) \times 0.60$ and $f_{\mathrm{OM}} \times 0.40$, respectively. The correction factors of 0.60 and 0.40 were estimated based on the data from Rogge et al. (1993). These factors were previously verified through a sensitivity study (Shahpoury et al., 2016). We assumed two scenarios for model calculations: $f_{\mathrm{BC}}=0.03$ and $f_{\mathrm{OM}}=0.30$, and $f_{\mathrm{BC}}=0.06$ and $f_{\mathrm{OM}}=0.60$. This resulted in $f_{\mathrm{WSOM}}$ and $f_{\mathrm{OP}}$ of 0.18 and 0.12 , and 0.36 and 0.24 for the two scenarios, respectively. The contributions of inorganic salts and PM aqueous phase to the overall sorption process were neglected; we acknowledge that under high relative humidity, salts may be present in aqueous phase, and subject to liquid-liquid phase separation with PM organic matter (You et al., 2014). The individual partitioning constants used in the multi-phase model were calculated using substance-specific Abraham descriptors listed in Table S2 and ppLFER models listed in Table S3 (Goss et al., 2003; Roth et al., 2005; Kamprad and Goss, 2007; Abraham et al., 2010).

See Shahpoury et al. (2016) for more details about calculation with multi-phase models and Endo and Goss (2014) for background on the ppLFER concept. The predicted $K_{\mathrm{P}}$ values were converted to $\theta$ under two scenarios with $c_{\mathrm{PM}}$ of 25 and $50 \mu \mathrm{g} \mathrm{m}^{-3}$ (Eq. 5):

$\theta=\frac{K_{\mathrm{P}} c_{\mathrm{PM}}}{\left(1+K_{\mathrm{P}} c_{\mathrm{PM}}\right)}$.

One must note that the ppLFER model used here predicts $K_{\mathrm{P}}$ of a substance in neutral form. In particulate phase, depending on $\mathrm{pH}$ of the $\mathrm{PM}$ aqueous phase and $p K_{\mathrm{a}}$ of the target substance, NMAHs may partly or completely deprotonate, resulting in enhanced solubility of the substance in the aqueous phase (Ahrens et al., 2012). This implies that the actual partitioning could be under-predicted for such substances. The effect is expected to be relevant for 5nitrosalicylic acid (5-NSA; see Table 2 for compound abbreviations) of $p K_{\mathrm{a}} 1.95$ at $298 \mathrm{~K}$ (Aydin et al.,1997), 3nitrosalicylic acid (3-NSA; we expect similar $p K_{\mathrm{a}}$ as that of 5-NSA), 2,4-DNP of $p K_{\mathrm{a}} 4.07$ at $298 \mathrm{~K}$ (Lide, 2010), 

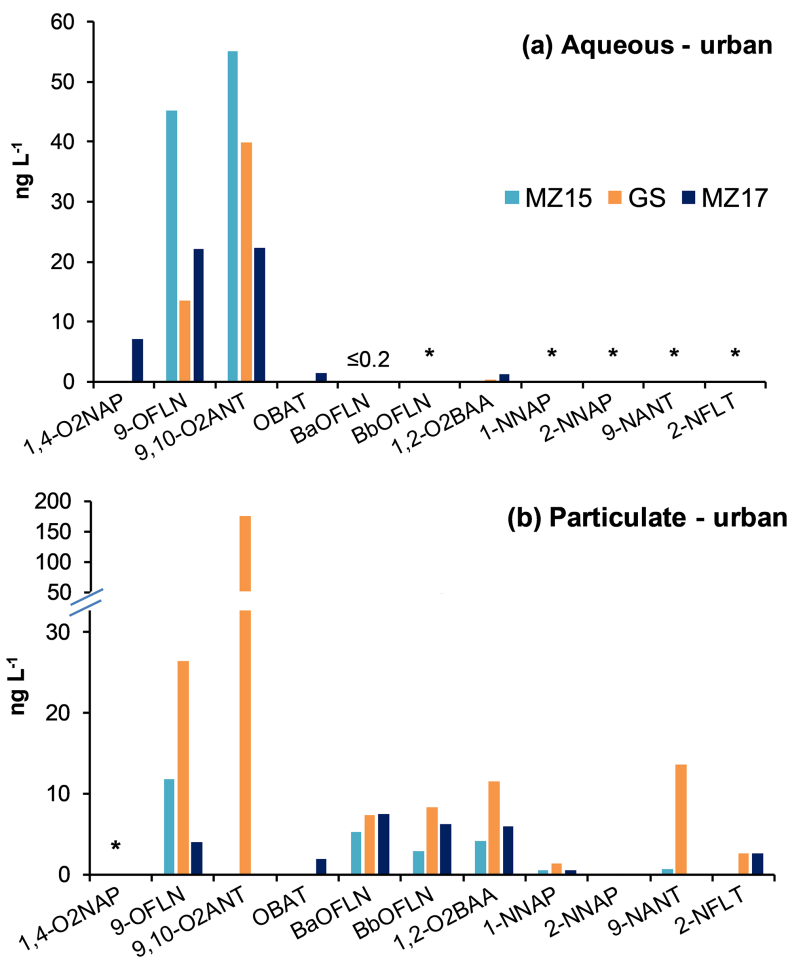

Figure 1. N/OPAHs in urban snow samples; * indicates values $<$ LOQ in all samples.

and DNOC of $p K_{\mathrm{a}} 4.48$ at $293 \mathrm{~K}$ (WHO, 2000). The rest of NMAHs have noticeably higher $p K_{\mathrm{a}}$ values $-4-\mathrm{NP}$ of 7.15, 2-methyl-4-nitrophenol (2-M-4-NP) of 7.33, 3-methyl4-nitrophenol (3-M-4-NP) of 7.33, 4-nitrocatechol (4-NC) of 6.93 at $298 \mathrm{~K}$; we expect $p K_{\mathrm{a}}$ values for 4-methyl-5nitrocatechol (4-M-5-NC) and 3-methyl-5-nitrocatechol (3$\mathrm{M}-5-\mathrm{NC})$ to be close to that for 4-NC.

\subsection{Air mass history analysis}

The HYSPLIT (Draxler and Rolph, 2003) model was used to identify the air masses' 3 -day histories related to the snowfall events. The meteorological data $\left(1^{\circ} \times 1^{\circ}\right.$ resolution $)$ used were from the Global Data Assimilation System (GDAS, NCEP, USA). Air mass changes were identified based on weather charts (Berliner Wetterkarte, 2015), except for the sample site in Svalbard, TF, as the snow fell 2-3 days prior to sample collection. The results are presented in the Supplement (Text S1 and Fig. S2).

\section{Results and discussion}

\subsection{N/OPAH concentrations and distribution in snow}

Snow aqueous and particulate phases were analysed for N/OPAHs following the method described in Sect. 2.3. In
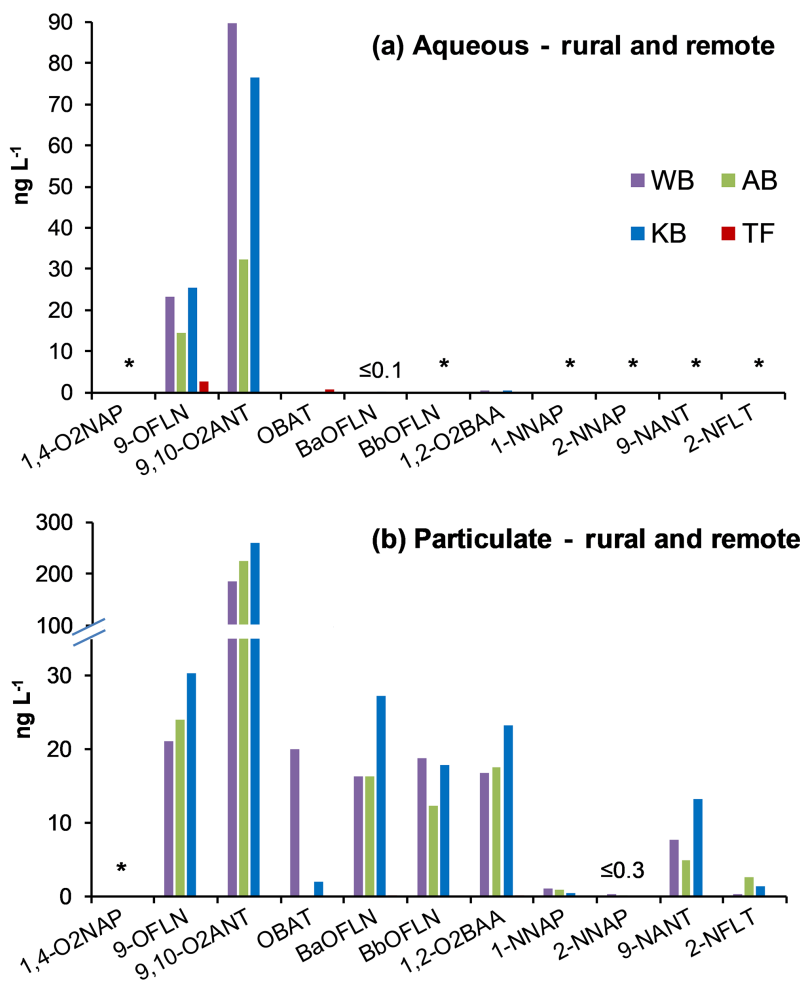

Figure 2. N/OPAHs in rural and remote snow samples; * indicates values $<$ LOQ in all samples.

the aqueous phase, 9-OFLN and 9,10- $\mathrm{O}_{2}$ ANT were found in nearly all samples, except at the remote site TF, where 9,10- $\mathrm{O}_{2}$ ANT was not found (Figs. 1a and 2a). 9,10- $\mathrm{O}_{2}$ ANT was the most abundant substance in the aqueous phase ( $\leq$ $\left.89.7 \mathrm{ng} \mathrm{L}^{-1}\right)$, followed by 9-OFLN $\left(\leq 45.3 \mathrm{ng} \mathrm{L}^{-1}\right)$. 1,2$\mathrm{O}_{2}$ BAA, 1,4- $\mathrm{O}_{2} \mathrm{NAP}$, OBAT, and BaOFLN were found less frequently, with relatively low concentrations in the aqueous phase (Figs. 1a and 2a). 9-OFLN and 9,10- $\mathrm{O}_{2}$ ANT originate from both primary (e.g. diesel exhaust, coal and biomass burning) and secondary sources, whereas OBAT and $\mathrm{BaOFLN}$ are associated with primary sources (see references in Sect. 1). Potential source areas for such emissions are reflected in the air mass histories of all samples (see Text S1 and Fig. S2 in the Supplement). Overall, TF and WB were the least and most polluted sites, with $\sum \mathrm{OPAH}$ aqueous concentrations of 3.2 and $113.6 \mathrm{ng} \mathrm{L}^{-1}$, respectively. NPAHs were not found in the snow aqueous phase. Our GPP model suggests that at near-zero temperatures the targeted NPAHs would be completely sorbed to the particulate phase in the atmosphere, with the exception 1-NNAP, 2-NNAP, 5-NACE, and 2-NFLU, which would partition between gas and particulate phases. Regardless, relatively low water solubility of NPAHs, indicated by their octanol-water partitioning coefficients ( $\log K_{\text {OW }}$; Fig. S3), may limit their gas scavenging from the atmosphere and subsequent presence in the snow aqueous phase. 


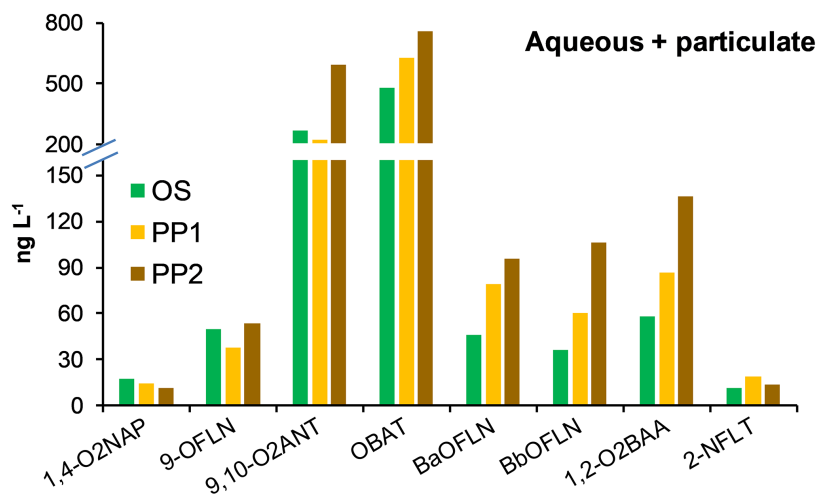

Figure 3. N/OPAHs in snow aqueous + particulate phase; urban and rural.

In the particulate phase of snow, four NPAHs and six OPAHs were detected (Figs. $1 b$ and $2 b$ ). Among all analytes, 9,10-O $\mathrm{O}_{2} \mathrm{ANT}$ (found in GS, WB, AB, and $\mathrm{KB}$ ) showed the highest concentrations of up to $242.2 \mathrm{ng} \mathrm{L}^{-1}$, followed by 9-OFLN (found in all but TF; $\leq 30.3 \mathrm{ng} \mathrm{L}^{-1}$ ), BaOFLN $\left(\leq 27.3 \mathrm{ng} \mathrm{L}^{-1}\right)$, and $1,2-\mathrm{O}_{2} \mathrm{BAA}\left(\leq 23.3 \mathrm{ng} \mathrm{L}^{-1}\right)$. The detected NPAHs in the particulate phase, 9-NANT, 2-NFLT, 1NNAP, and 2-nitronaphthalene (2-NNAP), showed relatively low concentrations up to 13.6, 2.6, 1.3, and $0.32 \mathrm{ng} \mathrm{L}^{-1}$, respectively (Figs. 1b and 2b). NPAHs found in the present study are the most frequently detected congeners in the gas (1- and 2-NNAP) and particulate (2-NFLT and 9-NANT) phases (Dimashki et al., 2000; Bamford and Baker, 2003; Albinet et al., 2006; Tomaz et al., 2016; Bandowe and Meusel, 2017), with 2-NFLT being exclusively formed through reaction of FLT with oxidants in the atmosphere (Bandowe and Meusel, 2017) and the other three NPAHs being produced by both primary and secondary sources (Zhuo et al., 2017). Overall, the remote site TF and rural site KB were the least and most polluted sites in the particulate phase, with $\sum \mathrm{N} / \mathrm{OPAH}$ concentrations of 0.3 and $375.4 \mathrm{ng} \mathrm{L}^{-1}$, respectively (Fig. 2b).

Snow samples OS, PP1, and PP2 were not phaseseparated for N/OPAH analysis. Out of all targeted NPAHs, only 2-NFLT (11.6-19.1 $\mathrm{ng} \mathrm{L}^{-1}$ ) was found at these sites (Fig. 3; Table S4a). Among OPAHs, OBAT, and 9,10$\mathrm{O}_{2}$ ANT showed the highest concentrations up to 758.1 and $595.3 \mathrm{ng} \mathrm{L}^{-1}$, respectively, whereas 1,2- $\mathrm{O}_{2} \mathrm{BAA}$, BbOFLN, BaOFLN, 9-OFLN, and 1,4- $\mathrm{O}_{2}$ NAP were relatively less abundant (Fig. 3; Table S4a). N/OPAH concentrations were overall higher at the rural sites PP1 and PP2 than the urban site OS (Table S4a). In terms of total N/OPAH concentrations (i.e. aqueous + particulate) across all sites, TF and PP2 were the least and most polluted sites (Table S4a). NPAHs contributed up to $11 \%$ to the particulate phase and up to $6 \%$ to the total concentrations across the samples. The predominance of OBAT, 9,10-O ${ }_{2}$ ANT, and 9-OFLN in our study is consistent with previous findings in the literature (Albinet et
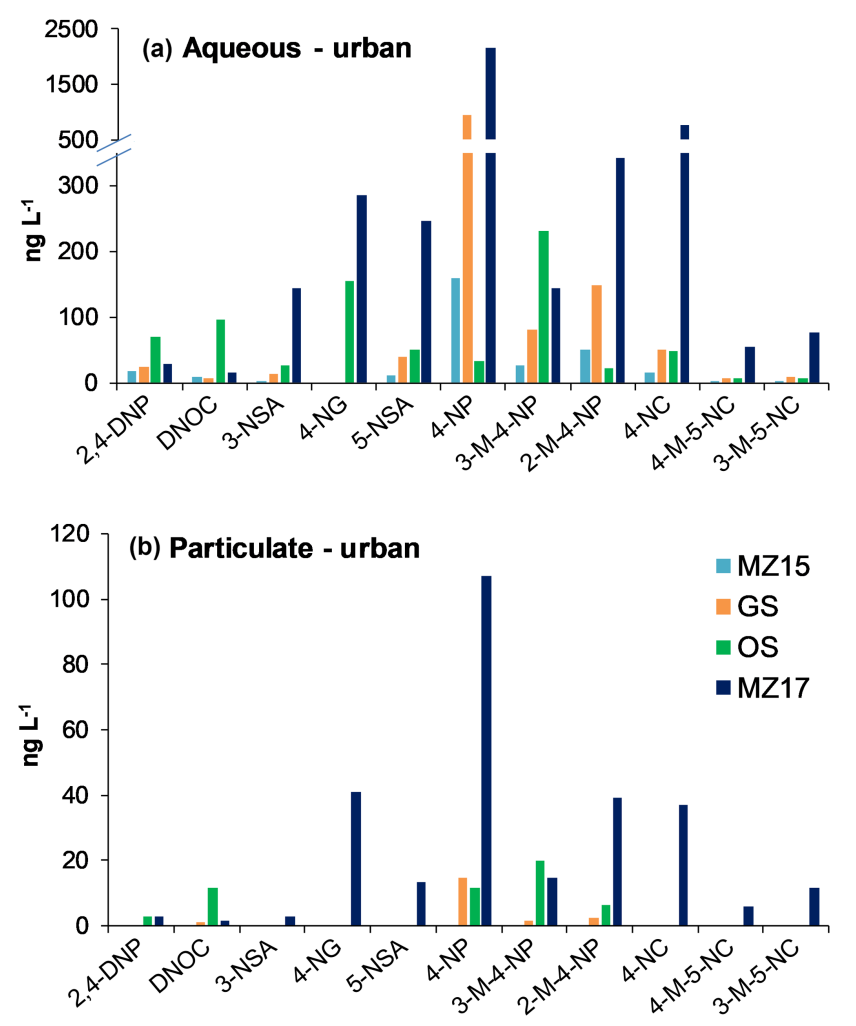

Figure 4. NMAHs in urban snow samples.

al., 2007; Souza et al., 2014; Lin et al., 2015; Tomaz et al., 2016). High abundance of OBAT is of particular concern because this compound is a precursor of the mutagenic 2- and 3-nitrobenzanthrone (Enya et al., 1997; Phousongphouang and Arey, 2003).

\subsection{NMAH concentrations and distribution in snow}

NMAHs targeted for analysis were found in all aqueous phase samples, with the exception of 4-nitroguaiacol (4NG), which was found less frequently (Figs. 4a and 5a). 4-NP showed the highest aqueous concentrations up to $2155.4 \mathrm{ng} \mathrm{L}^{-1}$, followed by 4-NC $\left(\leq 763.6 \mathrm{ng} \mathrm{L}^{-1}\right)$, 3-M-4$\mathrm{NP}\left(\leq 547.3 \mathrm{ng} \mathrm{L}^{-1}\right), 2-\mathrm{M}-4-\mathrm{NP}\left(\leq 341.1 \mathrm{ng} \mathrm{L}^{-1}\right)$, and 5NSA $\left(\leq 313.5 \mathrm{ng} \mathrm{L}^{-1}\right)$. In this phase, $4-\mathrm{NG}$ was exclusively found in urban samples OS and MZ17 (Fig. 4a) as well as rural and remote sites PP1, PP2, and TF (Fig. 5a). Overall in the aqueous phase, TF and MZ17 were the least and most polluted samples, with $\sum \mathrm{NMAH}$ concentrations of 390.5 and $4252.6 \mathrm{ng} \mathrm{L}^{-1}$, respectively (Figs. $4 \mathrm{a}$ and 5a).

The NMAHs were less abundant in the snow particulate phase (Figs. 4b and 5b). 4-NP was found in all samples, with concentrations up to $106.9 \mathrm{ng} \mathrm{L}^{-1}$ (MZ17), followed by 2-M-4-NP $\left(\leq 39.2 \mathrm{ng} \mathrm{L}^{-1}\right), 3-\mathrm{M}-4-\mathrm{NP}\left(\leq 21.8 \mathrm{ng} \mathrm{L}^{-1}\right)$, and DNOC ( $\leq 11.8 \mathrm{ng} \mathrm{L}^{-1}$; Figs. $4 \mathrm{~b}$ and $\left.5 \mathrm{~b}\right)$. Interestingly, 4-NP was the only NMAH found at the remote site TF. The rest of NMAHs were more sporadic in the particulate phase, with 

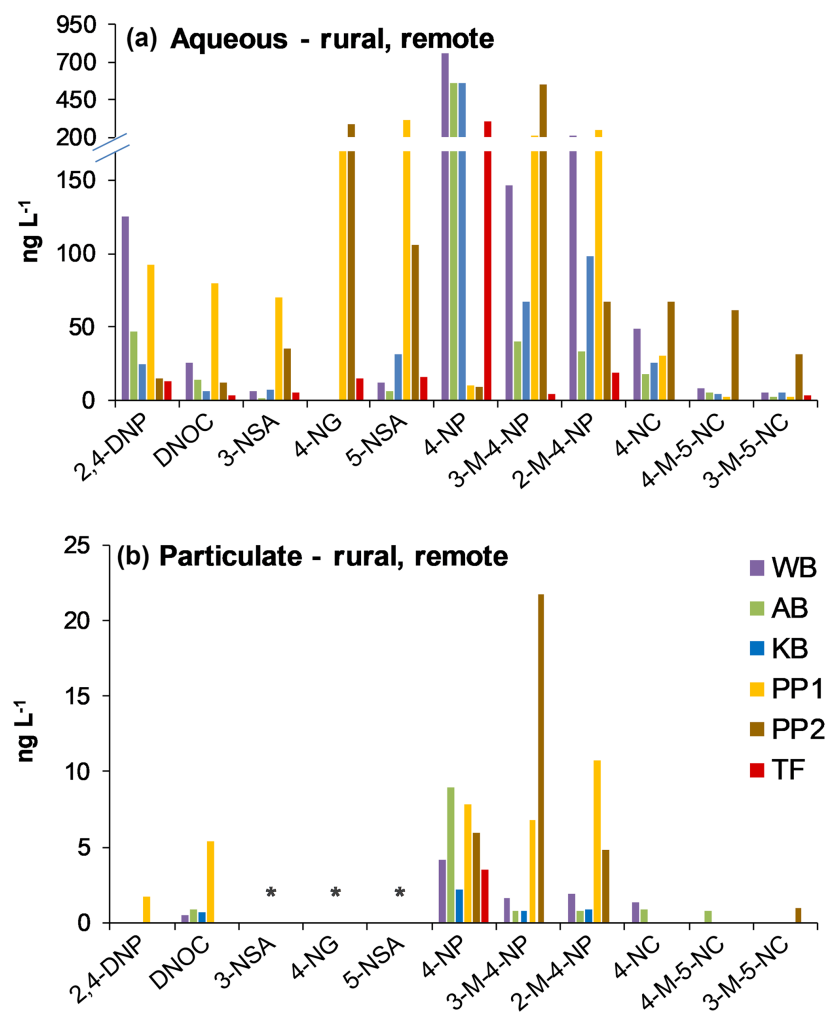

Figure 5. NMAHs in rural and remote snow samples.

3-NSA, 4-NG, and 5-NSA being found exclusively at the urban site MZ17 (Fig. 4b). Overall in the particulate phase, the remote site TF was the cleanest ( $\sum$ NMAHs: $3.5 \mathrm{ng} \mathrm{L}^{-1}$ ) and the urban site MZ17 was the most polluted ( $\sum$ NMAHs: $276.6 \mathrm{ng} \mathrm{L}^{-1}$ ) in our study.

The measured nitrophenol concentrations are in the same range as those reported previously for snow from central Europe and Antarctica (Alber et al., 1989; Vanni et al., 2001; Table S1), but lower (up to 2 orders of magnitude lower) than those reported in rainwater from central and northern Europe (Leuenberger et al., 1988; Herterich and Herrmann, 1990; Levsen et al., 1991; Bossi et al., 2002; Asman et al., 2005; Schummer et al., 2009; Table S1) and the USA (Ganranoo et al., 2010; Table S1). It must be noted that here we report the NMAH concentrations in both aqueous and particulate phases, which was not reported in the previous studies (Table S1). When detected, the aqueous phase concentrations of 4-NG were comparable in urban and rural samples ( 155-285 ng L ${ }^{-1}$; Figs. 4a and 5a), indicating polluted and aged air masses with biomass burning origin (Kitanovski et al., 2014; Kroflič et al., 2015; Yang et al., 2016). These values are 1 order of magnitude higher than that measured for the remote sample TF (Fig. 5a). In urban samples, with the exception of OS, nitrocatechols (4-NC and isomeric methylnitrocatechols) were the second most abundant NMAHs, following nitrophenols (Table S4a). This is in agreement with our current unpublished data and previous studies on winter
PM samples (Kitanovski et al., 2012). In contrast, in rural samples KB and PP1, and the remote sample TF, nitrosalicylic acids are the second most abundant NMAH species (Table S4a), which might indicate either higher stability or higher formation of these compounds during the transport of polluted air to the rural environments and the Arctic.

\subsection{Modelled particulate mass fractions and actual fractions removed by particle scavenging}

The target compound $\theta$ was estimated following the method explained in Sect. 2.6. We examined three scenarios, i.e. a lower, middle, and upper scenario with regard to pollution: (1) with $f_{\mathrm{BC}}$ and $f_{\mathrm{OM}}$ of 0.03 and 0.30 and $c_{\mathrm{PM}}$ of $25 \mu \mathrm{g} \mathrm{m}{ }^{-3}$, (2) $f_{\mathrm{BC}}$ and $f_{\mathrm{OM}}$ of 0.06 and 0.60 and $c_{\mathrm{PM}}$ of $25 \mu \mathrm{g} \mathrm{m}^{-3}$, and (3) $f_{\mathrm{BC}}$ and $f_{\mathrm{OM}}$ of 0.06 and 0.60 and $c_{\mathrm{PM}}$ of $50 \mu \mathrm{g} \mathrm{m} \mathrm{m}^{-3}$. In fact, the $24 \mathrm{~h}$ mean $c_{\mathrm{PM}}$ values for MZ17 and OS sampling events were 25 and $27 \mu \mathrm{g} \mathrm{m}^{-3}$, respectively. No data are available from the other sites. As can be seen in Fig. 6ac, $\theta$ at $273 \mathrm{~K}$ is $\sim 1$ (complete sorption to $\mathrm{PM}$ ) for $70 \%$ of the target compounds, independent of the above scenarios. The calculations showed that $<20 \%$ of 1-NNAP, 2-NNAP, 1,4- $\mathrm{O}_{2} \mathrm{NAP}, 9-\mathrm{OFLN}, 2,4-\mathrm{DNP}$, and DNOC, and between 20 and $80 \%$ of 5 -NACE, 2-NFLN, 3-NSA, and 4-NG can be expected to be in the particulate phase at $273 \mathrm{~K}$ (Fig. 6). For these substances, $\theta$ increases by up to 2-fold when increasing $f_{\mathrm{BC}}, f_{\mathrm{OM}}$, or $c_{\mathrm{PM}}$. An interesting trend was seen for 2,4-DNP and 4-NP: the presence of two nitro groups on 2,4-DNP is expected to promote stronger $\mathrm{H}$-bonding with $\mathrm{PM}$, compared to 4-NP which has one nitro group (compare the Abraham descriptor $B$ for the two compounds in Table S2). However, our model calculations suggest the opposite pattern, i.e. complete sorption of 4-NP to PM, but $<5 \%$ sorption for 2,4-DNP. This is largely related to intramolecular H-bonding between the $\mathrm{H}$ atom of the hydroxy group and the $\mathrm{O}$ atom of the nitro group in ortho position. This reduces the H-bonding ability of 2,4-DNP compared to 4-NP (compare the Abraham descriptor $A$ in Table S2).

For substances that demonstrate complete sorption to PM, particle scavenging is expected to be the dominant source of wet deposition and, consequently, such substances will be enriched in the precipitation particulate phase. Our observations depicted in Fig. 7a support this assumption; i.e. N/OPAHs with high $\theta$ (Fig. 6a-b) were largely associated with precipitation particulate phase. The only exception was 9,10- $\mathrm{O}_{2}$ ANT in MZ15 and MZ17 samples. For substances that distribute between gas and particulate phases, both gas and particle scavenging are relevant; however, the substance water solubility is a factor that could enhance or limit the gas scavenging mechanism, regardless of the compound phase partitioning in the atmosphere. For instance, 1- and 2-NNAP are expected to be $\geq 90 \%$ in the gas phase under our experimental conditions; nonetheless, they were found in the precipitation particulate phase. A similar effect was seen for 9-OFLN. This is explained by the substances' relatively low 

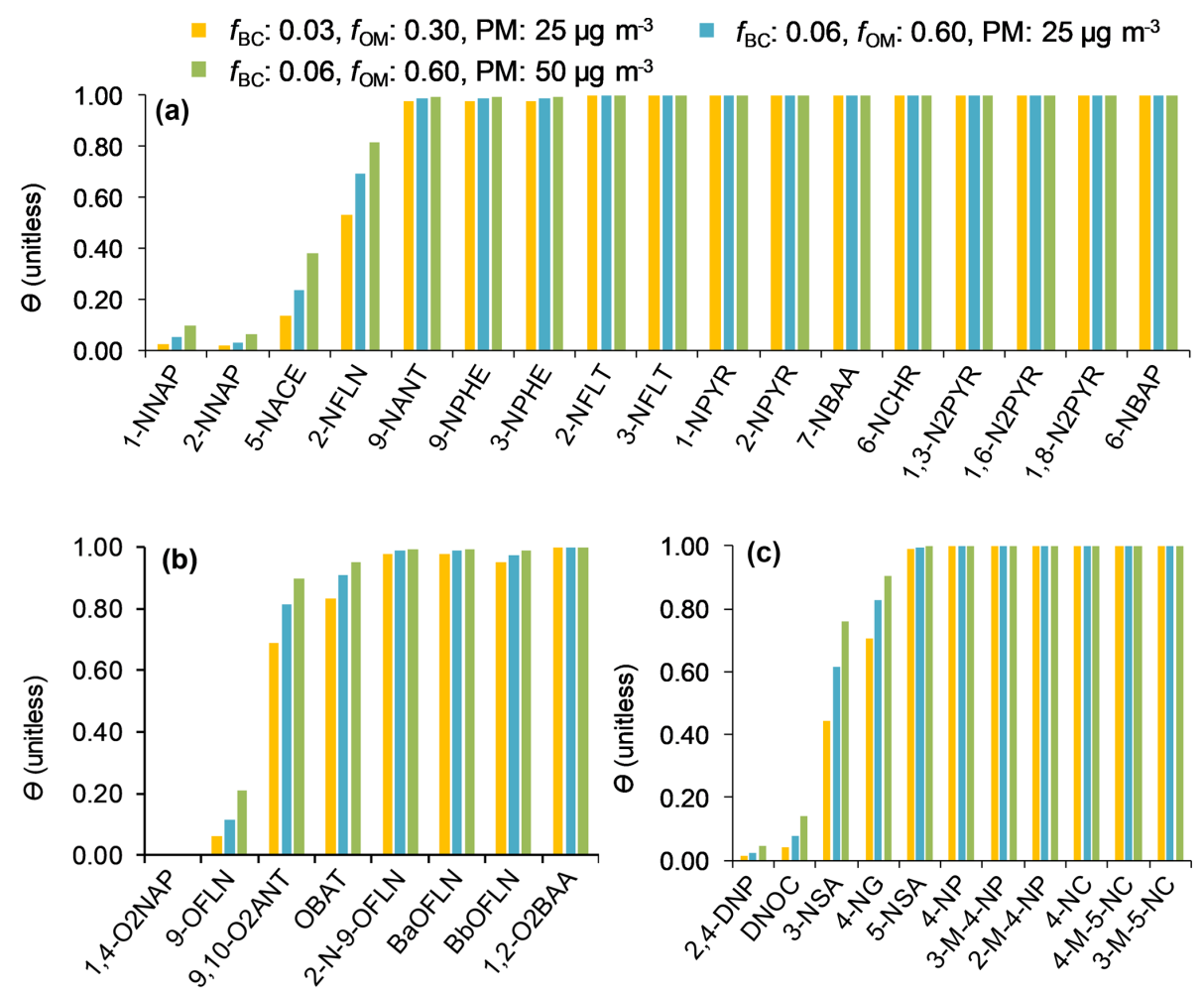

Figure 6. Particulate mass fractions $\theta$ estimated at $273 \mathrm{~K}$ using a multi-phase gas-particle partitioning model for NPAHs (a), OPAHs (b), and NMAHs (c).

water solubility (see estimated $K_{\text {Ow }}$ in Fig. S3), which limits their dissolution in hydrometeors. On the contrary, 1,4$\mathrm{O}_{2}$ NAP $(\theta: 0.001-0.003)$ was more enriched in the aqueous phase, which is explained by its relatively low $\log K_{\mathrm{OW}}$ (2.13; Fig. S3). Overall, our findings support the implied assumption that phase partitioning in air is preserved in snow, provided that the substance solubility in water is not a limiting factor.

The observation for NMAHs, however, is considerably different (Fig. 7b). These substances were mainly found in the aqueous phase, including the seven analytes for which complete sorption to PM was predicted under various scenarios. Among all, 4-NP showed the highest fraction in the precipitation particulate phase and was, as predicted, higher than 2,4-DNP; this was more pronounced in urban and rural samples OS, PP1, and PP2. The opposite pattern observed for NMAHs may suggest that besides GPP another process influenced the substance wet scavenging and consequently their distribution in precipitation phases. We rule out postsampling dissolution of NMAHs from particulate to aqueous phase for the reasons mentioned in Sect. 2.2 and hypothesize that, following both in- and below-cloud scavenging into subcooled droplets, particulate-phase NMAHs would dissolve into the bulk water or water layer surrounding ice hydrometeors (Hoff et al., 1995). This process is, at least partly, affected by the substance water solubility and, therefore, is antici- pated to be more efficient for highly water soluble substances such as NMAHs $\left(s=0.3-10 \mathrm{~g} \mathrm{~L}^{-1}, \log K_{\mathrm{OW}}=0.64-2.54\right.$; Fig. S3). This hypothesis is consistent with the results of a previous study where positive correlation was found between in-cloud scavenging efficiencies of PM-bound polar organics and the substance polarity (Limbeck and Puxbaum, 2000). This process (which potentially results in predominance of NMAHs in the aqueous phase), however, must be distinguished from the gas scavenging that was proposed by Leuenberger et al. (1985) as a dominant process for removal of volatile methylated phenols, where the predominance of these substances in the aqueous phase corresponded to their abundance in the gas phase.

For the urban site OS, the analyte concentrations in the gas and particulate phases of the air have been determined (sample collected over $24 \mathrm{~h}$ preceding snowfall onset; Table S4b) in addition to concentrations in precipitation. The scavenging ratios $W_{T}$ calculated for the target N/OPAHs and NMAHs (see Eq. 3) were $10^{3}-10^{4}$ and $10^{3}-10^{5}$, respectively (Table S4b), which fall within the range suggested for removal of polyaromatic compounds through wet particle scavenging (Shahpoury et al., 2015). With the exception of 1,4$\mathrm{O}_{2}$ NAP and 9-OFLN, the range of calculated $W_{T}$ is consistent with that of modelled $\theta$ at $273 \mathrm{~K}$ (Table S4b), meaning that the particle scavenging was the dominant removal mechanism. The difference in $W_{T}$ between 3- and 5-NSA 

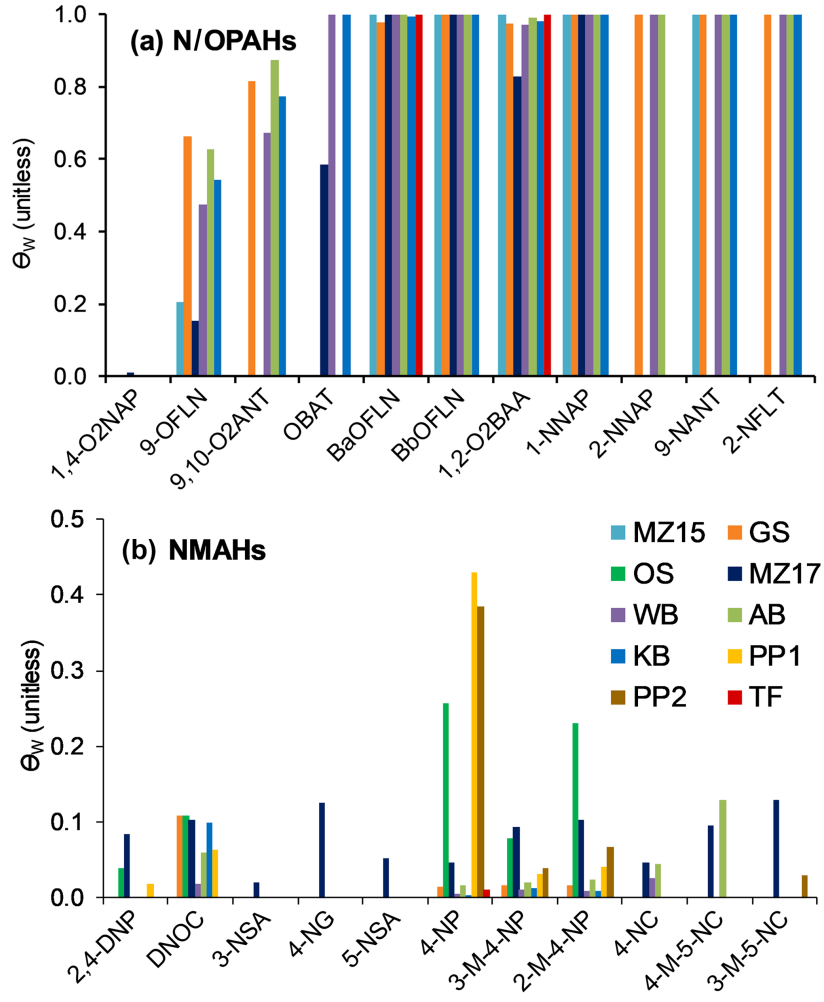

Figure 7. Fraction of N/OPAHs (a) and NMAHs (b) removed by particle scavenging $\left(\theta_{\mathrm{W}}\right)$.

$\left(\sim 1.4\right.$ times higher for 5-NSA) and between $9,10-\mathrm{O}_{2}$ ANT and OBAT $(\sim 1.1$ times higher for OBAT) closely resembled that of estimated $\theta$ at $273 \mathrm{~K}$ (Table S4b). However, we found differences in $W_{T}$ between the NMAH subgroups; i.e. $W_{T}$ values were higher for nitrophenols $\left(1.3 \times 10^{4}-1.6 \times 10^{5}\right)$ and nitrosalicylic acids $\left(5.7 \times 10^{4}-8.2 \times 10^{4}\right)$ than nitrocatechols $\left(1.1 \times 10^{3}-2.8 \times 10^{3}\right.$; Table S4B $)$, which cannot be explained by the substances' GPP alone (compare $\theta$ in Fig. 6c). Although based on a single precipitation event, these results are an indication of additional atmospheric processes that NMAHs could undergo and that may affect their wet scavenging. For instance, PM size-dependent mass distribution is a parameter that was suggested to influence the snow scavenging efficiencies (Zhang et al., 2013) - i.e. low efficiency in the PM size range $0.01-1 \mu \mathrm{m}$. This parameter should be taken into account in future studies, and more precipitation episodes need to be considered in order to draw a full picture.

\section{Final remarks}

The phase-separated concentrations of nitrated and oxygenated aromatic compounds were measured in snow from several locations in central Europe and the European Arctic. For the first time, we have reported the snow concentra- tions for several classes of nitrated and oxygenated aromatics, such as nitrocatechols, nitrosalicylic acids, nitrated and oxygenated PAHs, and 4-nitroguaiacol. Our results showed that a model-predicted particulate mass fraction, $\theta$, can be reliably applied in order to predict the scavenging mechanism (gas or particle scavenging) and efficiency of hydrophobic N/OPAHs and, hence, their distribution in precipitation phases, i.e. aqueous and particulate. This suggests that the atmospheric lifetime of N/OPAHs in relation to removal processes follows the same pattern as that of parent PAHs (Sharma and McBean, 2002). On the contrary, $\theta$ is not a good measure for predicting phase distribution of hydrophilic NMAHs in precipitation. Our data suggest that the phase distribution of polar particulate phase substances, such as NMAHs in snow, is determined by an interplay between GPP in the aerosol and dissolution in cloud or rain droplets, or the liquid water phase on the surface of ice hydrometeors during in- or below-cloud scavenging. This behaviour is in line with what was found for in-cloud scavenging of other polar mono- and difunctional organics, such as aliphatic alcohols, aliphatic and monoaromatic aldehydes, and carboxylic acids (Limbeck and Puxbaum, 2000); i.e. the polarity of these substances is a significant parameter for their scavenging when solubility is $>1 \mathrm{gL}^{-1}$. The experimental data on GPP of NMAHs are scarce in the literature, which was also not addressed here. The contribution of gaseous polar NMAHs to the total scavenging, beyond the scope of this study, should be addressed, as should other polar aliphatic and aromatic organics (Limbeck and Puxbaum, 2000).

Data availability. The dataset used in this paper is included in the Supplement, and further information is available from the corresponding author (p.shahpoury@mpic.de).

Supplement. The supplement related to this article is available online at: https://doi.org/10.5194/acp-18-13495-2018-supplement.

Author contributions. GL and PS designed the campaign. PS conducted the field work. PS and ZK carried out the sample processing as well as chemical and data analysis for N/OPAHs and NMAHs, respectively. PS performed and interpreted the GPP model simulations. GL provided meteorological analysis. PS wrote the paper with contributions from ZK and GL.

Competing interests. The authors declare that there is no conflict of interest.

Acknowledgements. We thank Paulo C. Alarcón, Thorsten Hoffmann (Max Planck Institute for Chemistry, Mainz), Pernilla Carlsson (University Centre in Svalbard, Longyearbyen), Ulrike Nickus (University of Innsbruck), Libor Černikovský (Czech 
Hydrometeorological Institute, Ostrava), Roman Prokeš, Ondřej Šáňka, Petra Přibylová, and Petr Kukučka (RECETOX, Brno) for on-site and laboratory support, and Landesamt für Umwelt Rheinland-Pfalz (ZIMEN network) for PM data. We also thank Roland Kallenborn (Norwegian University of Life Sciences) for supporting us with his research infrastructure, and Michael H. Abraham (University College London) for providing descriptors for the ppLFER model. This research was supported by the Max Planck Society and the Czech Science Foundation (no. P503 16-11537S).

The article processing charges for this open-access publication were covered by the Max Planck Society.

Edited by: Leiming Zhang

Reviewed by: three anonymous referees

\section{References}

Abraham, M. H., Smith, R. E., Luchtefeld, R., Boorem, A. J., Lou, R., and Acree, W. E.: Prediction of solubility of drugs and other compounds in organic solvents, J. Pharm. Sci., 99, 1500-1515, https://doi.org/10.1002/jps.21922, 2010.

Ahrens, L., Harner, T., Shoeib, M., Lane, D. A., and Murphy, J. G.: Improved characterization of gas-particle partitioning for perand polyfluoroalkyl substances in the atmosphere using annular diffusion denuder samplers, Environ. Sci. Technol., 46, 71997206, https://doi.org/10.1021/es300898s, 2012.

Alber, M., Böhm, H. B., Brodesser, J., Feltes, J., Levsen, K., and Schöler, H. F.: Determination of nitrophenols in rain and snow, Fresen. Z. Anal. Chem., 334, 540-545, https://doi.org/10.1007/BF00483573, 1989.

Albinet, A., Leoz-Garziandia, E., Budzinski, H., and Villenave, E.: Simultaneous analysis of oxygenated and nitrated polycyclic aromatic hydrocarbons on standard reference material 1649a (urban dust) and on natural ambient air samples by gas chromatography-mass spectrometry with negative ion chemical ionisation, J. Chromatogr. A, 1121, 106-113, https://doi.org/10.1016/j.chroma.2006.04.043, 2006.

Albinet, A., Leoz-Garziandia, E., Budzinski, H., and Villenave, E.: Polycyclic aromatic hydrocarbons (PAHs), nitrated PAHs and oxygenated PAHs in ambient air of the Marseilles area (South of France): concentrations and sources, Sci. Total Environ., 384, 280-292, https://doi.org/10.1016/j.scitotenv.2007.04.028, 2007.

Albinet, A., Nalin, F., Tomaz, S., Beaumont, J., and Lestremau, F.: A simple QuEChERS-like extraction approach for molecular chemical characterization of organic aerosols: application to nitrated and oxygenated PAH derivatives (NPAH and OPAH) quantified by GC-NICIMS, Anal. Bioanal. Chem., 406, 3131-3148, https://doi.org/10.1007/s00216-014-7760-5, 2014.

Arey, J., Zielinska, B., Atkinson, R., Winer, A. M., Ramdahl, T., and Pitts, J. N.: The formation of nitro-PAH from the gasphase reactions of fluoranthene and pyrene with the $\mathrm{OH}$ radical in the presence of $\mathrm{NO}_{x}$, Atmos. Environ., 20, 2339-2345, https://doi.org/10.1016/0004-6981(86)90064-8, 1986.

Asman, W. A. H., Jørgensen, A., Bossi, R., Vejrup, K. V., Bügel Mogensen, B., and Glasius, M.: Wet deposition of pesticides and nitrophenols at two sites in Denmark: measurements and con- tributions from regional sources, Chemosphere, 59, 1023-1031, https://doi.org/10.1016/j.chemosphere.2004.11.048, 2005.

Atlas, E. and Giam, C. S.: Ambient concentration and precipitation scavenging of atmospheric organic pollutants, Water Air Soil Poll., 38, 19-36, https://doi.org/10.1007/BF00279583, 1988.

Aydin, R., Özer, U., and Türkel, N.: Potentiometric and spectroscopic determinaton of acid dissociation constants of some phenols and salicylic acids, Turk. J. Chem., 21, 428-436, 1997.

Bamford, H. A. and Baker, J. E.: Nitro-polycyclic aromatic hydrocarbon concentrations and sources in urban and suburban atmospheres of the Mid-Atlantic region, Atmos. Environ., 37, 20772091, https://doi.org/10.1016/S1352-2310(03)00102-X, 2003.

Bandowe, B. A. M. and Meusel, H.: Nitrated polycyclic aromatic hydrocarbons (nitro-PAHs) in the environment - a review, Sci. Total Environ., 581-582, 237-257, https://doi.org/10.1016/j.scitotenv.2016.12.115, 2017.

Bartels-Rausch, T., Jacobi, H.-W., Kahan, T. F., Thomas, J. L., Thomson, E. S., Abbatt, J. P. D., Ammann, M., Blackford, J. R., Bluhm, H., Boxe, C., Domine, F., Frey, M. M., Gladich, I., Guzmán, M. I., Heger, D., Huthwelker, Th., Klán, P., Kuhs, W. F., Kuo, M. H., Maus, S., Moussa, S. G., McNeill, V. F., Newberg, J. T., Pettersson, J. B. C., Roeselová, M., and Sodeau, J. R.: A review of air-ice chemical and physical interactions (AICI): liquids, quasi-liquids, and solids in snow, Atmos. Chem. Phys., 14, 1587-1633, https://doi.org/10.5194/acp-14-1587-2014, 2014.

Belloli, R., Bolzacchini, E., Clerici, L., Rindone, B., Sesana, G., and Librando, V.: Nitrophenols in air and rainwater, Environ. Eng. Sci., 23, 405-415, https://doi.org/10.1089/ees.2006.23.405, 2006.

Berliner Wetterkarte: Daily Charts (CD-ROM version), Verein Berliner Wetterkarte, e.V., available at: http: //www.berliner-wetterkarte.de (last access: 20 August 2017), 2015.

Bidleman, T. F.: Atmospheric processes, Environ. Sci. Technol., 22, 361-367, https://doi.org/10.1021/es00169a002, 1988.

Bluvshtein, N., Lin, P., Flores, J. M., Segev, L., Mazar, Y., Tas, E., Snider, G., Weagle, C., Brown, S. S., Laskin, A., and Rudich, Y.: Broadband optical properties of biomassburning aerosol and identification of brown carbon chromophores, J. Geophys. Res.-Atmos., 122, 5441-5456, https://doi.org/10.1002/2016JD026230, 2017.

Borrowman, C. K., Zhou, S. M., Burrow, T. E., and Abbatt, J. P. D.: Formation of environmentally persistent free radicals from the heterogeneous reaction of ozone and polycyclic aromatic compounds, Phys. Chem. Chem. Phys., 18, 205-212, https://doi.org/10.1039/c5cp05606c, 2016.

Bossi, R., Vejrup, K., Mogensen, B., and Asman, W. A. .: Analysis of polar pesticides in rainwater in Denmark by liquid chromatography-tandem mass spectrometry, J. Chromatogr. A, 957, 27-36, https://doi.org/10.1016/S0021-9673(02)00312-6, 2002.

Caumo, S. E. S., Claeys, M., Maenhaut, W., Vermeylen, R., Behrouzi, S., Safi Shalamzari, M., and Vasconcellos, P. C.: Physicochemical characterization of winter $\mathrm{PM}_{10}$ aerosol impacted by sugarcane burning from São Paulo city, Brazil, Atmos. Environ., 145, 272-279, https://doi.org/10.1016/j.atmosenv.2016.09.046, 2016.

Charrier, J. G., McFall, A. S., Richards-Henderson, N. K., and Anastasio, C.: Hydrogen peroxide formation in a sur- 
rogate lung fluid by transition metals and quinones present in particulate matter, Environ. Sci. Technol., 48, 7010-7017, https://doi.org/10.1021/es501011w, 2014.

Cho, A. K., Di Stefano, E., You, Y., Rodriguez, C. E., Schmitz, D. A., Kumagai, Y., Miguel, A. H., Eiguren-Fernandez, A., Kobayashi, T., Avol, E. and Froines, J. R.: Determination of four quinones in diesel exhaust particles, SRM 1649a, and atmospheric $\mathrm{PM}_{2.5}$, Aerosol Sci. Tech., 38, 68-81, https://doi.org/10.1080/02786820390229471, 2004.

Choudhury, D. R.: Characterization of polycyclic ketones and quinones in diesel emission particulates by gas chromatography/mass spectrometry, Environ. Sci. Technol., 16, 102-106, https://doi.org/10.1021/es00096a009, 1982.

Chow, K. S., Huang, X. H. H., and Yu, J. Z.: Quantification of nitroaromatic compounds in atmospheric fine particulate matter in Hong Kong over 3 years: field measurement evidence for secondary formation derived from biomass burning emissions, Environ. Chem., 13, 665-673, https://doi.org/10.1071/EN15174, 2016.

Chung, M. Y., Lazaro, R. A., Lim, D., Jackson, J., Lyon, J., Rendulic, D., and Hasson, A. S.: Aerosol-borne quinones and reactive oxygen species generation by particulate matter extracts, Environ. Sci. Technol., 40, 4880-4886, https://doi.org/10.1021/es0515957, 2006.

Dimashki, M.: Measurements of nitro-PAH in the atmospheres of two cities, Atmos. Environ., 34, 2459-2469, https://doi.org/10.1016/S1352-2310(99)00417-3, 2000.

Ding, J., Zhong, J., Yang, Y., Li, B., Shen, G., Su, Y., Wang, C., Li, W., Shen, H., Wang, B., Wang, R., Huang, Y., Zhang, Y., Cao, H., Zhu, Y., Simonich, S. L. M., and Tao, S.: Occurrence and exposure to polycyclic aromatic hydrocarbons and their derivatives in a rural Chinese home through biomass fuelled cooking, Environ. Pollut., 169, 160-166, https://doi.org/10.1016/j.envpol.2011.10.008, 2012.

Draxler, R. R. and Rolph, G. D.: HYSPLIT (hybrid single-particle lagrangian integrated trajectory) model access via NOAA ARL READY, NOAA Air Resour. Lab., Silver Springs, USA, available at: http://www.arl.noaa.gov/ready/hysplit4.html (last access: July 2017), 2003.

Endo, S. and Goss, K. U.: Applications of polyparameter linear free energy relationships in environmental chemistry, Environ. Sci. Technol., 48, 12477-12491, https://doi.org/10.1021/es503369t, 2014.

Enya, T., Suzuki, H., Watanabe, T., Hirayama, T., and Hisamatsu, Y.: 3-Nitrobenzanthrone, a powerful bacterial mutagen and suspected human carcinogen found in diesel exhaust and airborne particulates, Environ. Sci. Technol., 31, 2772-2776, https://doi.org/10.1021/es961067i, 1997.

Finlayson-Pitts, B. and Pitts, J. N.: Chemistry of the upper and lower atmosphere: theory, experiments, application, Academic Press, San Diego, CA, USA, 2000.

Ganranoo, L., Mishra, S. K., Azad, A. K., Shigihara, A., Dasgupta, P. K., Breitbach, Z. S., Armstrong, D. W., Grudpan, K., and Rappenglueck, B.: Measurement of nitrophenols in rain and air by two-dimensional liquid chromatography-chemically active liquid core waveguide spectrometry, Anal. Chem., 82, 5838-5843, https://doi.org/10.1021/ac101015y, 2010.

Goss, K.-U., Buschmann, J., and Schwarzenbach, R. P.: Determination of the surface sorption properties of talc, different salts, and clay minerals at various relative humidities using adsorption data of a diverse set of organic vapors, Environ. Toxicol. Chem., 22, 2667-2672, https://doi.org/10.1897/03-56, 2003.

Harrison, M. A. J., Barra, S., Borghesi, D., Vione, D., Arsene, C., and Iulian Olariu, R.: Nitrated phenols in the atmosphere: a review, Atmos. Environ., 39, 231-248, https://doi.org/10.1016/j.atmosenv.2004.09.044, 2005.

Herterich, R. and Herrmann, R.: Comparing the distribution of nitrated phenols in the atmosphere of two German hill sites, Environ. Technol., 11, 961-972, https://doi.org/10.1080/09593339009384948, 1990.

Hinrichs, R. Z., Buczek, P., and Trivedi, J. J.: Solar absorption by aerosol-bound nitrophenols compared to aqueous and gaseous nitrophenols, Environ. Sci. Technol., 50, 5661-5667, https://doi.org/10.1021/acs.est.6b00302, 2016.

Hoff, J. T., Wania, F., Mackay, D., and Gillham, R.: Sorption of nonpolar organic vapors by ice and snow, Environ. Sci. Technol., 29, 1982-1989, https://doi.org/10.1021/es00008a016, 1995.

Huang, Q., Wang, L., and Han, S.: The genotoxicity of substituted nitrobenzenes and the quantitative structureactivity relationship studies, Chemosphere, 30, 915-923, https://doi.org/10.1016/0045-6535(94)00450-9, 1995.

Huang, W., Huang, B., Bi, X., Lin, Q., Liu, M., Ren, Z., Zhang, G., Wang, X., Sheng, G., and Fu, J.: Emission of PAHs, NPAHs and OPAHs from residential honeycomb coal briquette combustion, Energ. Fuel., 28, 636-642, https://doi.org/10.1021/ef401901d, 2014.

Iinuma, Y., Brüggemann, E., Gnauk, T., Müller, K., Andreae, M. O., Helas, G., Parmar, R., and Herrmann, H.: Source characterization of biomass burning particles: the combustion of selected European conifers, African hardwood, savanna grass, and German and Indonesian peat, J. Geophys. Res., 112, D08209, https://doi.org/10.1029/2006JD007120, 2007.

Iinuma, Y., Böge, O., Gräfe, R., and Herrmann, H.: Methylnitrocatechols: atmospheric tracer compounds for biomass burning secondary organic aerosols, Environ. Sci. Technol., 44, 8453-8459, https://doi.org/10.1021/es102938a, 2010.

Jaber, F., Schummer, C., Al Chami, J., Mirabel, P. and Millet, M.: Solid-phase microextraction and gas chromatography-mass spectrometry for analysis of phenols and nitrophenols in rainwater, as their t-butyldimethylsilyl derivatives, Anal. Bioanal. Chem., 387, 2527-2535, https://doi.org/10.1007/s00216-0061115-9, 2007.

Jariyasopit, N., Zimmermann, K., Schrlau, J., Arey, J., Atkinson, R., Yu, T.-W., Dashwood, R. H., Tao, S. and Simonich, S. L. M.: Heterogeneous reactions of particulate matter-bound PAHs and NPAHs with $\mathrm{NO}_{3} / \mathrm{N}_{2} \mathrm{O}_{5}, \mathrm{OH}$ radicals, and $\mathrm{O}_{3}$ under simulated long-range atmospheric transport conditions: reactivity and mutagenicity, Environ. Sci. Technol., 48, 10155-10164, https://doi.org/10.1021/es5015407, 2014.

Jonker, M. T. O. and Koelmans, A. A.: Sorption of polycyclic aromatic hydrocarbons and polychlorinated biphenyls to soot and soot-like materials in the aqueous environment: mechanistic considerations, Environ. Sci. Technol., 36, 3725-3734, https://doi.org/10.1021/es020019x, 2002.

Kahnt, A., Behrouzi, S., Vermeylen, R., Safi Shalamzari, M., Vercauteren, J., Roekens, E., Claeys, M., and Maenhaut, W.: One-year study of nitro-organic compounds and their relation to wood burning in $\mathrm{PM}_{10}$ aerosol from 
a rural site in Belgium, Atmos. Environ., 81, 561-568, https://doi.org/10.1016/j.atmosenv.2013.09.041, 2013.

Kamprad, I. and Goss, K.-U.: Systematic investigation of the sorption properties of polyurethane foams for organic vapors, Anal. Chem., 79, 4222-4227, https://doi.org/10.1021/ac070265x, 2007.

Karavalakis, G., Deves, G., Fontaras, G., Stournas, S., Samaras, Z., and Bakeas, E.: The impact of soy-based biodiesel on PAH, nitro$\mathrm{PAH}$ and oxy-PAH emissions from a passenger car operated over regulated and nonregulated driving cycles, Fuel, 89, 3876-3883, https://doi.org/10.1016/j.fuel.2010.07.002, 2010.

Kawamura, K. and Kaplan, I. R.: Organic compounds in the rainwater of Los Angeles, Environ. Sci. Technol., 17, 497-501, https://doi.org/10.1021/es00114a011, 1983.

Kelly, F. J. and Fussell, J. C.: Role of oxidative stress in cardiovascular disease outcomes following exposure to ambient air pollution, Free Radical Bio. Med., 110, 345-367, https://doi.org/10.1016/j.freeradbiomed.2017.06.019, 2017.

Keyte, I. J., Harrison, R. M., and Lammel, G.: Chemical reactivity and long-range transport potential of polycyclic aromatic hydrocarbons - a review, Chem. Soc. Rev., 42, 9333-9391, https://doi.org/10.1039/C3CS60147A, 2013.

Kitanovski, Z., Grgić, I., Vermeylen, R., Claeys, M., and Maenhaut, W.: Liquid chromatography tandem mass spectrometry method for characterization of monoaromatic nitro-compounds in atmospheric particulate matter, J. Chromatogr. A, 1268, 35-43, https://doi.org/10.1016/j.chroma.2012.10.021, 2012.

Kitanovski, Z., Čusak, A., Grgić, I., and Claeys, M.: Chemical characterization of the main products formed through aqueous-phase photonitration of guaiacol, Atmos. Meas. Tech., 7, 2457-2470, https://doi.org/10.5194/amt-7-2457-2014, 2014.

Kohler, M. and Heeb, N. V: Determination of nitrated phenolic compounds in rain by liquid chromatography/atmospheric pressure chemical ionization mass spectrometry, Anal. Chem., 75, 31153121, https://doi.org/10.1021/ac0264067, 2003.

Kojima, Y., Inazu, K., Hisamatsu, Y., Okochi, H., Baba, T., and Nagoya, T.: Influence of secondary formation on atmospheric occurrences of oxygenated polycyclic aromatic hydrocarbons in airborne particles, Atmos. Environ., 44, 2873-2880, https://doi.org/10.1016/j.atmosenv.2010.04.048, 2010.

Kovacic, P. and Somanathan, R.: Nitroaromatic compounds: environmental toxicity, carcinogenicity, mutagenicity, therapy and mechanism, J. Appl. Toxicol., 34, 810-824, https://doi.org/10.1002/jat.2980, 2014.

Kroflič, A., Grilc, M., and Grgić, I.: Does toxicity of aromatic pollutants increase under remote atmospheric conditions?, Sci. Rep., 5, 8859, https://doi.org/10.1038/srep08859, 2015.

Lammel, G.: Polycyclic aromatic compounds in the atmosphere - a review identifying research needs, Polycycl. Aromat. Comp., 35, 316-329, https://doi.org/10.1080/10406638.2014.931870, 2015.

Leuenberger, C., Ligocki, M. P., and Pankow, J. F.: Trace organic compounds in rain. 4 , Identities, concentrations, and scavenging mechanisms for phenols in urban air and rain, Environ. Sci. Technol., 19, 1053-1058, https://doi.org/10.1021/es00141a005, 1985.

Leuenberger, C., Czuczwa, J., Tremp, J., and Giger, W.: Nitrated phenols in rain: atmospheric occurrence of phytotoxic pollutants, Chemosphere, 17, 511-515, https://doi.org/10.1016/00456535(88)90026-4, 1988.
Levsen, K., Behnert, S., Prieß, B., Svoboda, M., Winkeler, H.-D., and Zietlow, J.: Organic compounds in precipitation, Chemosphere, 21, 1037-1061, https://doi.org/10.1016/00456535(90)90127-F, 1990.

Levsen, K., Behnert, S., and Winkeler, H. D.: Organic compounds in precipitation, Fresen. J. Anal. Chem., 340, 665-671, https://doi.org/10.1007/BF00321532, 1991.

Levsen, K., Behnert, S., Mußmann, P., Raabe, M. and Prieß, B.: Organic compounds in cloud and rain water, Int. J. Environ. Anal. Chem., 52, 87-97, https://doi.org/10.1080/03067319308042851, 1993.

Lide, D. R.: CRC Handbook of Chemistry and Physics, 90th Edition (CD-ROM Version), CRC Press, Boca Raton, FL, 2010.

Limbeck, A. and Puxbaum, H.: Dependence of in-cloud scavenging of polar organic aerosol compounds on the water solubility, J. Geophys. Res., 105, 19857-19867, https://doi.org/10.1029/2000JD900123, 2000.

Lin, P., Aiona, P. K., Li, Y., Shiraiwa, M., Laskin, J., Nizkorodov, S. A., and Laskin, A.: Molecular characterization of brown carbon in biomass burning aerosol particles, Environ. Sci. Technol., 50, 11815-11824, https://doi.org/10.1021/acs.est.6b03024, 2016.

Lin, Y., Ma, Y., Qiu, X., Li, R., Fang, Y., Wang, J., Zhu, Y., and $\mathrm{Hu}, \mathrm{D} .:$ Sources, transformation, and health implications of PAHs and their nitrated, hydroxylated, and oxygenated derivatives in $\mathrm{PM}_{2.5}$ in Beijing, J. Geophys. Res., 120, 7219-7228, https://doi.org/10.1002/2015JD023628, 2015.

Lodovici, M. and Bigagli, E.: Oxidative Stress and Air Pollution Exposure, J. Toxicol., 2011, 1-9, https://doi.org/10.1155/2011/487074, 2011.

Mohr, C., Lopez-Hilfiker, F. D., Zotter, P., Prévoît, A. S. H., Xu, L., Ng, N. L., Herndon, S. C., Williams, L. R., Franklin, J. P., Zahniser, M. S., Worsnop, D. R., Knighton, W. B., Aiken, A. C., Gorkowski, K. J., Dubey, M. K., Allan, J. D., and Thornton, J. A.: Contribution of nitrated phenols to wood burning brown carbon light absorption in Detling, United Kingdom during winter time, Environ. Sci. Technol., 47, 6316-6324, https://doi.org/10.1021/es400683v, 2013.

Møller, P., Danielsen, P. H., Karottki, D. G., Jantzen, K., Roursgaard, M., Klingberg, H., Jensen, D. M., Christophersen, D. V., Hemmingsen, J. G., Cao, Y., and Loft, S.: Oxidative stress and inflammation generated DNA damage by exposure to air pollution particles, Mutat. Res., 762, 133-166, https://doi.org/10.1016/j.mrrev.2014.09.001, 2014.

Pflieger, M. and Kroflič, A.: Acute toxicity of emerging atmospheric pollutants from wood lignin due to biomass burning, J. Hazard. Mater., 338, 132-139, https://doi.org/10.1016/j.jhazmat.2017.05.023, 2017.

Pham, C. T., Kameda, T., Toriba, A. and Hayakawa, K.: Polycyclic aromatic hydrocarbons and nitropolycyclic aromatic hydrocarbons in particulates emitted by motorcycles, Environ. Pollut., 183, 175-183, https://doi.org/10.1016/j.envpol.2013.01.003, 2013.

Phousongphouang, P. T. and Arey, J.: Sources of the atmospheric contaminants, 2-nitrobenzanthrone and 3-nitrobenzanthrone, Atmos. Environ., 37, 3189-3199, https://doi.org/10.1016/S13522310(03)00344-3, 2003.

Poster, D. L. and Baker, J. E.: Influence of submicron particles on hydrophobic organic contaminants in precipitation, 2. scavenging of polycyclic aromatic hydrocarbons by rain, Environ. 
Sci. Technol., 30, 349-354, https://doi.org/10.1021/es940681w, 1996.

Rippen, G., Zietz, E., Frank, R., Knacker, T., and Klöpffer, W.: Do airborne nitrophenols contribute to forest decline?, Environ. Technol. Lett., 8, 475-482, https://doi.org/10.1080/09593338709384508, 1987.

Rogge, W. F., Mazurek, M. A., Hildemann, L. M., Cass, G. R., and Simoneit, B. R. T.: Quantification of urban organic aerosols at a molecular level: identification, abundance and seasonal variation, Atmos. Environ., 27, 1309-1330, https://doi.org/10.1016/09601686(93)90257-Y, 1993.

Roth, C. M., Goss, K.-U., and Schwarzenbach, R. P.: Sorption of a diverse set of organic vapors to diesel soot and road tunnel aerosols, Environ. Sci. Technol., 39, 6632-6637, https://doi.org/10.1021/es049204w, 2005.

Schummer, C., Groff, C., Al Chami, J., Jaber, F., and Millet, M.: Analysis of phenols and nitrophenols in rainwater collected simultaneously on an urban and rural site in east of France, Sci. Total Environ., 407, 5637-5643, https://doi.org/10.1016/j.scitotenv.2009.06.051, 2009.

Schüssler, W. and Nitschke, L.: Nitrophenols in precipitation, Chemosphere, 42, 277-283, https://doi.org/10.1016/S00456535(00)00086-2, 2001

Shahpoury, P., Lammel, G., Holubová Šmejkalová, A., Klánová, J., Přibylová, P., and Váňa, M.: Polycyclic aromatic hydrocarbons, polychlorinated biphenyls, and chlorinated pesticides in background air in central Europe - investigating parameters affecting wet scavenging of polycyclic aromatic hydrocarbons, Atmos. Chem. Phys., 15, 1795-1805, https://doi.org/10.5194/acp15-1795-2015, 2015.

Shahpoury, P., Lammel, G., Albinet, A., Sofuoglu, A., Dumanoğlu, Y., Sofuoglu, S. C., Wagner, Z., and Zdimal, V.: Evaluation of a conceptual model for gas-particle partitioning of polycyclic aromatic hydrocarbons using polyparameter linear free energy relationships, Environ. Sci. Technol., 50, 12312-12319, https://doi.org/10.1021/acs.est.6b02158, 2016.

Sharma, M. and McBean, E. A.: Atmospheric PAH deposition: deposition velocities and washout ratios, J. Environ. Eng., 128, 186-195, https://doi.org/10.1061/(ASCE)07339372(2002)128:2(186), 2002.

Shen, G., Tao, S., Wei, S., Zhang, Y., Wang, R., Wang, B., Li, W., Shen, H., Huang, Y., Chen, Y., Chen, H., Yang, Y., Wang, W., Wang, X., Liu, W., and Simonich, S. L. M.: Emissions of parent, nitro, and oxygenated polycyclic aromatic hydrocarbons from residential wood combustion in rural China, Environ. Sci. Technol., 46(15), 8123-8130, https://doi.org/10.1021/es301146v, 2012.

Shen, G., Xue, M., Wei, S., Chen, Y., Wang, B., Wang, R., Lv, Y., Shen, H., Li, W., Zhang, Y., Huang, Y., Chen, H., Wei, W., Zhao, Q., Li, B., Wu, H., and Tao, S.: Emissions of parent, nitrated, and oxygenated polycyclic aromatic hydrocarbons from indoor corn straw burning in normal and controlled combustion conditions, J. Environ. Sci., 25, 2072-2080, https://doi.org/10.1016/S10010742(12)60249-6, 2013a.

Shen, G., Tao, S., Wei, S., Chen, Y., Zhang, Y., Shen, H., Huang, Y., Zhu, D., Yuan, C., Wang, H., Wang, Y., Pei, L., Liao, Y., Duan, Y., Wang, B., Wang, R., Lv, Y., Li, W., Wang, $\mathrm{X}$., and Zheng, X.: Field measurement of emission factors of PM, EC, OC, parent, nitro-, and oxy- polycyclic aromatic hy- drocarbons for residential briquette, coal cake, and wood in rural Shanxi, China, Environ. Sci. Technol., 47, 2998-3005, https://doi.org/10.1021/es304599g, 2013b.

Škrdlíková, L., Landlová, L., Klánová, J., and Lammel, G.: Wet deposition and scavenging efficiency of gaseous and particulate phase polycyclic aromatic compounds at a central European suburban site, Atmos. Environ., 45, 4305-4312, https://doi.org/10.1016/j.atmosenv.2011.04.072, 2011.

Souza, K. F., Carvalho, L. R. F., Allen, A. G., and Cardoso, A. A.: Diurnal and nocturnal measurements of PAH, nitro-PAH, and oxy-PAH compounds in atmospheric particulate matter of a sugar cane burning region, Atmos. Environ., 83, 193-201, https://doi.org/10.1016/j.atmosenv.2013.11.007, 2014

Teich, M., van Pinxteren, D., Wang, M., Kecorius, S., Wang, Z., Müller, T., Močnik, G., and Herrmann, H.: Contributions of nitrated aromatic compounds to the light absorption of watersoluble and particulate brown carbon in different atmospheric environments in Germany and China, Atmos. Chem. Phys., 17, 1653-1672, https://doi.org/10.5194/acp-17-1653-2017, 2017.

Tomaz, S., Shahpoury, P., Jaffrezo, J.-L., Lammel, G., Perraudin, E., Villenave, E., and Albinet, A.: One-year study of polycyclic aromatic compounds at an urban site in Grenoble (France): seasonal variations, gas/particle partitioning and cancer risk estimation, Sci. Total Environ., 565, 1071-1083, https://doi.org/10.1016/j.scitotenv.2016.05.137, 2016.

Tremp, J., Mattrel, P., Fingler, S., and Giger, W.: Phenols and nitrophenols as tropospheric pollutants: Emissions from automobile exhausts and phase transfer in the atmosphere, Water. Air. Soil Poll., 68, 113-123, https://doi.org/10.1007/BF00479396, 1993.

Vanni, A., Pellegrino, V., Gamberini, R., and Calabria, A.: An Evidence for nitrophenols contamination in Antarctic fresh-water and snow. Simultaneous determination of nitrophenols and nitroarenes at ng/L levels, Int. J. Environ. An. Ch., 79, 349-365, https://doi.org/10.1080/03067310108044394, 2001.

Vicente, E. D., Vicente, A. M., Musa Bandowe, B. A., and Alves, C. A.: Particulate phase emission of parent polycyclic aromatic hydrocarbons (PAHs) and their derivatives (alkyl-PAHs, oxygenated-PAHs, azaarenes and nitrated PAHs) from manually and automatically fired combustion appliances, Air Qual. Atmos. Hlth., 9, 653-668, https://doi.org/10.1007/s11869-0150364-1, 2016.

Walgraeve, C., Demeestere, K., Dewulf, J., Zimmermann, R., and Van Langenhove, H.: Oxygenated polycyclic aromatic hydrocarbons in atmospheric particulate matter: Molecular characterization and occurrence, Atmos. Environ., 44, 1831-1846, https://doi.org/10.1016/j.atmosenv.2009.12.004, 2010.

Watanabe, M. and Noma, Y.: Influence of combustion temperature on formation of nitro-PAHs and decomposition and removal behaviors in pilot-scale waste incinerator, Environ. Sci. Technol., 43, 2512-2518, https://doi.org/10.1021/es8035169, 2009.

WHO: World Health Organization, environmental health criteria 220, dinitro-ortho-cresol, Geneva, Schwitzerland, 2000.

Yang, B., Zhang, H., Wang, Y., Zhang, P., Shu, J., Sun, W. and Ma, P.: Experimental and theoretical studies on gas-phase reactions of $\mathrm{NO}_{3}$ radicals with three methoxyphenols: guaiacol, creosol, and syringol, Atmos. Environ., 125, 243-251, https://doi.org/10.1016/j.atmosenv.2015.11.028, 2016.

You, Y., Smith, M. L., Song, M., Martin, S. T., and Bertram, A. K.: Liquid-liquid phase separation in atmospheri- 
cally relevant particles consisting of organic species and inorganic salts, Int. Rev. Phys. Chem., 33, 43-77, https://doi.org/10.1080/0144235X.2014.890786, 2014.

Zhang, L., Wang, X., Moran, M. D., and Feng, J.: Review and uncertainty assessment of size-resolved scavenging coefficient formulations for below-cloud snow scavenging of atmospheric aerosols, Atmos. Chem. Phys., 13, 10005-10025, https://doi.org/10.5194/acp-13-10005-2013, 2013.
Zhuo, S., Du, W., Shen, G., Li, B., Liu, J., Cheng, H., Xing, B., and Tao, S.: Estimating relative contributions of primary and secondary sources of ambient nitrated and oxygenated polycyclic aromatic hydrocarbons, Atmos. Environ., 159, 126-134, https://doi.org/10.1016/j.atmosenv.2017.04.003, 2017.

Zielinska, B., Sagebiel, J., McDonald, J. D., Whitney, K., and Lawson, D. R.: Emission rates and comparative chemical composition from selected in-use diesel and gasolinefueled vehicles, JAPCA J. Air Waste Ma., 54, 1138-1150, https://doi.org/10.1080/10473289.2004.10470973, 2004. 